\title{
Fibrinogen-like protein 1 (FGL1): the next immune checkpoint target
}

\author{
Wenjing Qian ${ }^{1,2 \dagger}$, Mingfang Zhao ${ }^{3 \dagger}$, Ruoyu Wang ${ }^{1,2^{*}}$ and Heming $\mathrm{Li}^{3^{*}}$ (D)
}

\begin{abstract}
Immune checkpoint therapy has achieved significant efficacy by blocking inhibitory pathways to release the function of T lymphocytes. In the clinic, anti-programmed cell death protein 1/programmed cell death ligand 1 (PD-1/PD-L1) monoclonal antibodies (mAbs) have progressed to first-line monotherapies in certain tumor types. However, the efficacy of anti-PD-1/PD-L1 mAbs is still limited due to toxic side effects and de novo or adaptive resistance. Moreover, other immune checkpoint target and biomarkers for therapeutic response prediction are still lacking; as a biomarker, the PD-L1 (CD274, B7-H1) expression level is not as accurate as required. Hence, it is necessary to seek more representative predictive molecules and potential target molecules for immune checkpoint therapy. Fibrinogen-like protein 1 (FGL1) is a proliferation- and metabolism-related protein secreted by the liver. Multiple studies have confirmed that FGL1 is a newly emerging checkpoint ligand of lymphocyte activation gene 3 (LAG3), emphasizing the potential of targeting FGL1/LAG3 as the next generation of immune checkpoint therapy. In this review, we summarize the substantial regulation mechanisms of FGL1 in physiological and pathological conditions, especially tumor epithelial to mesenchymal transition, immune escape and immune checkpoint blockade resistance, to provide insights for targeting FGL1 in cancer treatment.
\end{abstract}

Keywords: FGL1, LAG-3, Biomarker, Immune resistance, Immune checkpoint blockade

\section{Background}

Immune checkpoints (ICs) are essential in modulating the immune response and mediate $\mathrm{T}$ cell dysfunction in autoimmunity and inflammation [1-5]. However, these inhibitory pathways can be educated by tumor cells and promote tumor immune escape [6-8]. Recent cancer immune checkpoint blockade therapies have aimed to reverse such $\mathrm{T}$ cell exhaustion by targeting immune

\footnotetext{
*Correspondence: wangruoyu1963@hotmail.com;

liheming8563@hotmail.com

${ }^{\dagger}$ Wenjing Qian and Mingfang Zhao have contributed equally as first authors

1 Department of Oncology, Affiliated Zhongshan Hospital of Dalian University, No. 6 Jiefang Street, Dalian, Liaoning 110006, People's Republic of China

${ }^{3}$ Department of Medical Oncology, the First Hospital of China Medical University, No.155 Nanjingbei Road, Shenyang, Liaoning 110001, People's Republic of China

Full list of author information is available at the end of the article
}

checkpoints "to release the brakes", which allows cytotoxic $\mathrm{T}$ cells to attack tumor cells [4, 9-11]. In recent years, targeted cytotoxic $\mathrm{T}$ lymphocyte-associated antigen-4 (CTLA-4) and/or PD-1/PD-L1 therapies have been used in the treatment of clinically advanced tumors and have achieved high rates of objective remission [12-14]. Unfortunately, several cancer patients receiving PD-1/ PD-L1 mAb therapy have exhibited pseudoprogression (PP) $[15,16]$ or hyperprogression (HP) [17-20]. Although $\mathrm{PP}$ is considered a rare phenomenon with varying incidence rates (approximately 1-10\%) in different tumors using different assessment criteria (Response Evaluation Criteria in Solid Tumors (RECIST) and immunerelated response criteria (irRC)), anti-PD-1/PD-L1 therapy still needs to be treated with caution to achieve higher survival benefits [15]. Additionally, previous studies reported that $9 \%$ of 131 evaluable patients were considered to have HP (defined as a twofold increase in the 
tumor growth rate between the reference and experimental periods) [17]. In addition, patients treated with nivolumab (a humanized mAb against PD-1) were found to be at a higher risk of developing side effects, such as interstitial pneumonia and colitis [21-25]. Most importantly, it has been confirmed that only $20 \%$ of patients benefit from immune checkpoint blockade therapy in clinical studies [26], with the rest of the patients showing primary or adaptive drug resistance to varying degrees [27-37]. Therefore, the efficacy of immunotherapy is not satisfactory. Thus, attention has turned to other effective immune checkpoint pathways in further studies [12, $38-41]$.

Recent studies have focused on one of the most promising immune checkpoints. LAG3 (CD223) is an inhibitory receptor expressed mainly on the surface of $\mathrm{T}$ lymphocytes $[26,42,43]$. The binding of LAG3 with its ligands delivers negative signals to activated $\mathrm{T}$ cells, preventing immune-mediated tissue damage [44]. Similar to PD-1/ PD-L1 [5, 45, 46], LAG3 has an inhibitory function based on interactions with its ligands, which include major histocompatibility complex II (MHC II) [47, 48], galectin-3 [49], liver sinusoidal endothelial cell lectin (LSECtin) and FGL1 [12, 50]. FGL1, also known as liver fibrinogenrelated gene-1 (LFIRE-1)/Hepassocin (HPS) or hepatocyte-derived fibrinogen-related protein-1 (HFREP-1) [51-53], is a proliferation- and metabolism-related factor secreted by the liver [54-56]. It has recently emerged as a novel ligand of LAG3 beyond the classic ligand MHC II and can bind with LAG3 to form a new immune checkpoint pathway independent of PD-1/PD-L1, which results in $\mathrm{T}$ cell depletion and subsequent dysfunction, as well as tumor cell escape from immune surveillance [50, 57]. Apart from its relatively high expression in the liver and pancreas, FGL1 is upregulated in tumor tissues (including lung, prostate, melanoma, colorectal, breast and brain tumors) based on several datasets [50]. Hence, FGL1 has potential as another immune checkpoint target in clinical practice, especially in targeted therapy for non-small cell lung cancer (NSCLC) [58-65]. In this review, we summarize the function and molecular mechanism of FGL1 in the regulation of cancer development and metastasis and provide promising applications in therapeutic strategies for malignant tumor treatment.

\section{FGL1 biological function and regulation of expression}

\section{Structure and distribution of FGL1}

FGL1 is located on human chromosome 8 (8p22-21.3) and is a $68-\mathrm{KD}$ protein comprised of a disulfide bondlinked homodimer $[66,67]$. Its carboxyl terminus contains the $\beta$ and $\gamma$ subunits, which are highly homologous to fibrinogen but irrelevant to coagulation-related binding sites [50]. Under normal physiological conditions, FGL1 is secreted mainly by hepatocytes in the liver (some of which may also exist in the pancreas) [50]. It is now clear that FGL1 is the product of hepatocyte regeneration and participates in hepatocyte mitosis and liver energy utilization (including lipid metabolism and blood glucose regulation) [54, 68, 69]. Apart from the above functions, FGL1 can also be detected in the plasma as an acute reactant [70], implying that FGL1 secreted by the liver acts not only on hepatocytes (autocrine) but also on other tissues, such as muscle and brown adipose tissues (telecrine) (Fig. 1a) [56, 68]. Under stimulation by metabolic factors (hyperglycemia, hyperlipidemia, hormones, etc.), the liver secretes FGL1 and participates in the blood circulation $[52,69,71]$. This function of FGL1 acts on brown adipose tissue $[54,56]$, regulates body productivity and maintains body temperature. Moreover, FGL1 also acts on muscle tissue and affects the sensitivity of myoblasts to insulin $[52,68]$.

\section{Expression, regulation and function of FGL1 in benign disease}

Given that FGL1 is a physiological secretory factor of the liver, its expression can be regarded as a self-protective mechanism acting against exogenous injury or stimulation. FGL1 expression is regulated by radiation-induced lung, liver and stomach injury [71-73]. In addition, factors released by hepatectomy and postoperative inflammation (interleukin (IL)-6 and transforming growth factor (TGF)- $\beta$ ) can also affect the expression of FGL1 [70, 73-77]. Under such exogenous induction, normal hepatocytes regulate FGL1 transcription via signal transducer and activator of transcription 3 (STAT3) and hepatocyte nuclear factor- $1 \alpha$ (HNF-1 $\alpha)$ (Fig. 1b) [78-83]. FGL1 expression can also be regulated in chronic medical diseases, such as hyperlipidemia, insulin resistance, and hyperglycemia crisis. Hitherto, there have been studies on the mechanism of the FGL1-mediated regulation of substance metabolism in chronic diseases (Table 1). In clinical practice, changes in the FGL1 expression level can be specifically observed in type 2 diabetes patients with non-alcoholic liver disease [52]. Recently, plasma tests in these patients have found that FGL1 is upregulated when insulin resistance occurs. The high concentration of FGL1 in the plasma acts not only on itself but also on both adipocytes and myoblasts (Fig. 1a). In a hyperlipidemic model, palmitate-treated primary hepatocytes regulated the expression of FGL1 through CCAAT/ enhancer-binding protein $\beta(\mathrm{C} / \mathrm{EBP} \beta)$-mediated transcription, and the expression level of FGL1 in the liver of mice fed a high-fat diet (HFD) was also increased [68]. This high level of FGL1 could act on C2C12 cells (myoblasts) and generate insulin resistance through 


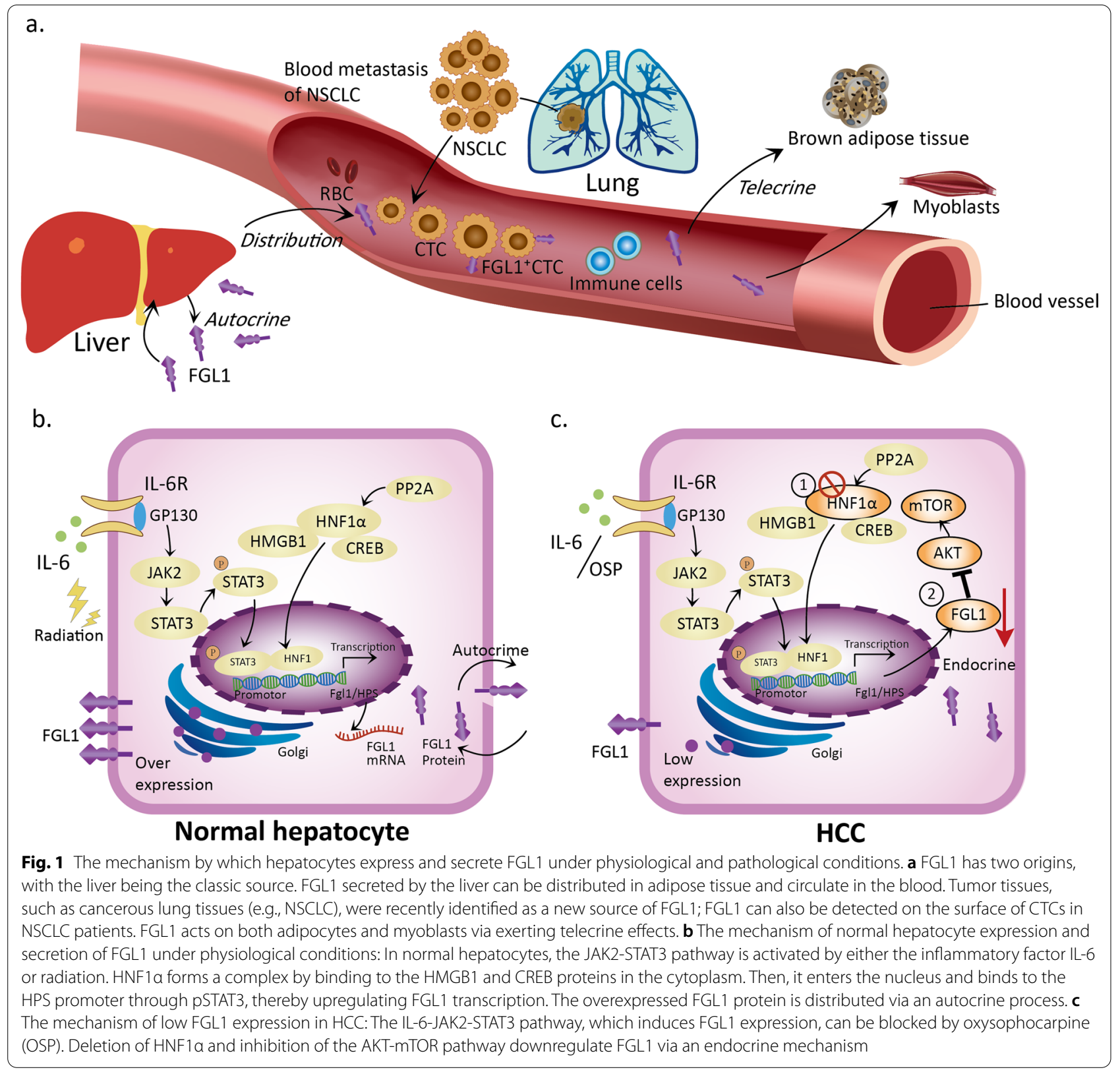

the phosphorylated JNK pathway [68]. In addition, in patients with type 2 diabetes, FGL1 induces insulin resistance in HepG2 cells via the hepatocyte-dependent extracellular regulated protein kinase (ERK) $1 / 2$ pathway [52]. Furthermore, in adipocytes, extracellular FGL1 induces adipogenesis through the canonical ERK1/2-C/ EBP $\beta$-peroxisome proliferator-activated receptor (PPAR) $\gamma$ pathway [56].

Apart from protecting hepatocytes (promoting regeneration and apoptosis) and regulating metabolism, FGL1 expression can also be used as a marker of some benign diseases (autoimmunity, infectious diseases, acute inflammation, etc.). First, the value of FGL1 can predict the activity of rheumatoid arthritis (RA; moderate/high: $91.46 \%$; remission/low: $80.77 \%$ ) and the severity of dengue fever $[84,85]$. Second, the fluctuation in FGL1 expression in vivo can also affect the progression of obesity and malaria parasite infection $[56,86]$. These above studies reveal that FGL1 plays important roles and acts as a potential biomarker in several common benign diseases. 
Table 1 Regulation of FGL1 expression in association with substance metabolism

\begin{tabular}{|c|c|c|c|c|}
\hline Stimulating factor & Induced cell type & Signaling pathway & Phenotype & References \\
\hline \multirow[t]{2}{*}{ FGL1 } & 3T3-L1 (adipocyte) & 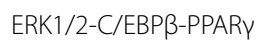 & FGL1-induced adipogenesis & {$[56]$} \\
\hline & HepG2 & ERK $1 / 2$ & Impair insulin sensitivity & [52] \\
\hline \multirow[t]{2}{*}{ Hyperglycemia } & HepG2 & ERK1/2-NRF2-SOD1 & Enhance antioxidative stress & [69] \\
\hline & & STAT3/HNF-1 & Upregulate FGL1 expression & \\
\hline Hyperlipidemia (Palmitate) & Primary hepatocyte & C/EBP $\beta$ & Upregulate FGL1 expression & {$[68]$} \\
\hline FGL1 & $\mathrm{C} 2 \mathrm{C} 12$ (myoblast) & JNK-p-JNK & Impair insulin sensitivity & \\
\hline Hepatectomy/IL-6 & Hepatocyte & HNF-1/STAT3/AP-1 & $\begin{array}{l}\text { Activate the FGL } 1 \text { and IGFBP-1 genes; } \\
\text { restore metabolic homeostasis }\end{array}$ & {$[74,78]$} \\
\hline
\end{tabular}

AP-1: activating protein-1; C/EBP 3 : CCAAT/enhancer-binding protein $\beta$; ERK1/2: extracellular regulated protein kinases 1/2; HNF-1: hepatocyte nuclear factor-1; IGFBP1: insulin-like growth factor binding protein 1; JNK: Jun N-terminal kinase; NRF2: nuclear factor erythroid-2-related factor 2; PPARY: peroxisome proliferator-activated receptor gamma; SOD1: superoxide dismutase 1; STAT3: signal transducer and activator of transcription 3

\section{Role of FGL1 in cancer development FGL1 is upregulated in solid tumors}

At present, studies on the regulation of FGL1 expression are not limited to the exploration of its physiological and pathological functions [87]. The expression of FGL1 in human solid tumors is different from that in paracancerous tissues. According to the bioGPS tissue microarray database and a proteomic analysis, both the mRNA and protein expression levels of FGL1 are mainly confined to the normal liver and pancreas in humans. A meta-analysis of Oncomine datasets showed that FGL1 expression was upregulated in lung, prostate, melanoma, colorectal, breast cancer and brain tumors but downregulated in pancreatic, breast, liver and head and neck cancers. Among these changes, the trends observed in lung, prostate and liver tumors were consistent with those in The Cancer Genome Atlas (TCGA) datasets, while FGL1 was significantly upregulated in the lung adenocarcinoma cancer map (FGL1 ranked 38th among the top 200 highly expressed genes in lung cancer). In addition, multiple quantitative immunofluorescence (QIF) staining was performed on a tissue microarray of 275 NSCLC samples to detect FGL1 protein expression in cells and tissues (Table 2). The data showed that the FGL1 protein was expressed in local pan-keratinpositive tumor cells but the stromal compartment exhibited almost no expression. These above results indicate that the expression of FGL1 is upregulated in human tumors, as represented by NSCLC [50]. Moreover, FGL1 is downregulated in hepatocellular carcinoma (HCC) in TCGA datasets. This result was also confirmed in a recent study showing that the expression of FGL1 could be downregulated due to the deletion of HNF1 $\alpha$ in HCC [51, 67, 78] (Fig. 1c). Hence, FGL1 is released at lower levels by HCC tumor tissues but at higher levels in other solid tumors.

\section{FGL1 mediates EMT process in tumors}

The process of tumor progression is accompanied by changes in angiogenesis, invasion and migration [88]. Tumor epithelial to mesenchymal transition (EMT) is not only reflected in changes in cell morphology but also closely related to the behaviors of tumor cell invasion and migration [89-92]. Previous preclinical studies have confirmed the correlation between FGL1 and the tumor EMT process in lung and gastric cancers [93, 94]. First, following FGL1 silencing in liver kinase B1 (LKB1)-mutant lung adenocarcinoma cells (A549 and H157 cells), E-cadherin was shown to be downregulated, while $\mathrm{N}$-cadherin and vimentin were upregulated [93, 95, 96]. However, another opposite conclusion was also reached: E-cadherin was upregulated and the expression of $\mathrm{N}$-cadherin and vimentin was suppressed when FGL1 was knocked out in SGC-7901 gastric cancer cells [94, 97-101]. Hence, the relationship between FGL1 and EMT progression in tumor cells still needs to be further investigated. In addition, a correlation between FGL1 and the EMT process has also been reported in a pulmonary fibrosis model, which is distinct from tumor models. Knockout of FGL1 impeded the processes of radiation- or TGF- $\beta$-induced EMT $[73,89]$. After silencing the FGL1 gene in L132 cells, EMT markers (increased: Snail [102], Twist [103], MMP12 and fibronectin [104-106]; decreased: ZO-1 $[107,108])$ changed at both the mRNA and protein levels. These above studies demonstrate that there is a correlation between FGL1 and the EMT process in tumors but the conclusions are not consistent. In the presence of FGL1, interstitial markers are downregulated, confirming that FGL1 modulates EMT under radiation or inflammatory induction [109]. This effect may be closely related to the protective effect of FGL1 in response to injury stimulation. As tumor EMT is tightly associated with prognosis and drug resistance [110-113], the specific mechanism by which FGL1 regulates tumor EMT needs to be clarified (Fig. 2). 
Table 2 Summary of the FGL1 detection in various human cancers as determined by a clinical approach

\begin{tabular}{|c|c|c|c|c|c|c|}
\hline No & Year & Tumor type & Numbers/samples & FGL1 detection methods & Conclusions & References \\
\hline 1 & 2020 & $B C$ & $\begin{array}{l}N=47, \text { primary tumor tissue; } \\
N=82, \text { peripheral blood }\end{array}$ & $\mathrm{IHC}$; flow cytometry & $\begin{array}{l}\text { FGL1 was present and tended to be expressed at } \\
\text { higher levels in stage III cancer cells than in stage } \\
\text { I or II cancer cells }\end{array}$ & [163] \\
\hline 2 & 2020 & $\mathrm{HCC}$ & $N=143$, primary tumor tissue & Multiplex IF & $\begin{array}{l}\text { High FGL } 1 \text { expression was negatively associ- } \\
\text { ated with PD-L1 expression and the CD8 }{ }^{+} \mathrm{T} \text { cell } \\
\text { density but positively associated with high } L A G 3^{+} \\
\text {T cell density }\end{array}$ & [165] \\
\hline 3 & 2019 & LUAD & $N=30$, primary tumor tissue & $\mathrm{IHC}$ & $\begin{array}{l}\text { Low FGL1 expression contributed to EMT and } \\
\text { angiogenesis in LKB1-low LUAD tissue samples }\end{array}$ & [93] \\
\hline \multirow[t]{3}{*}{4} & 2019 & NSCLC & $N=275$, plasma & Multiplex QIF & $\begin{array}{l}\text { FGL1 was shown to exhibit a relatively high } \\
\text { expression level in tumor cells compared with } \\
\text { the stromal distribution and paired normal } \\
\text { tissues; } 15 \% \text { NSCLC patients showed elevated } \\
\text { expression, implying a worse 5-year OS rate }\end{array}$ & {$[50]$} \\
\hline & & & $N=74$, plasma & ELISA & $\begin{array}{l}\text { Higher plasma FGL1 levels were detected in } \\
\text { NSCLC patients than in healthy donors; the } \\
\text { plasma FGL1 levels in NSCLC patients were not } \\
\text { associated with tumor metastasis or liver injury }\end{array}$ & \\
\hline & & & $N=18$, plasma & ELISA & $\begin{array}{l}\text { Higher plasma FGL1 levels were associated with } \\
\text { worse OS in NSCLC patients treated with anti- } \\
\text { PD-1/PD-L1 therapy }\end{array}$ & \\
\hline 5 & 2019 & MM & $N=21$, plasma & ELISA & $\begin{array}{l}\text { Higher plasma FGL1 levels were associated with } \\
\text { worse OS in metastatic melanoma patients } \\
\text { treated with anti-PD-1/PD-L1 therapy }\end{array}$ & \\
\hline 6 & 2019 & GC & $N=50$, primary tumor tissue & qPCR and WB & $\begin{array}{l}\text { Both the mRNA and protein levels of FGL1 were } \\
\text { obviously higher in GC tissues than in normal } \\
\text { tissues }(P<0.001) \text {; high FGL1 expression was } \\
\text { related to a poor prognosis }(P<0.01) \text {; the FGL1 } \\
\text { expression, pathological stage and histological } \\
\text { grade were positively associated with the OS of } \\
\text { GC patients }(P<0.05)\end{array}$ & [94] \\
\hline
\end{tabular}

BC: breast cancer; ELISA: sandwich enzyme-linked immunosorbent assay; GC: gastric cancer; IF: immunofluorescence staining; IHC: immunohistochemical staining; QIF: quantitative immunofluorescence staining; LUAD: lung adenocarcinoma; MM: melanoma; OS: overall survival; qPCR: quantitative PCR; WB: western blot

\section{FGL1 regulates other tumor characteristics}

Apart from mediating the EMT process, FGL1 is also involved in tumor proliferation, apoptosis, radiation and drug sensitivity [71, 72, 114-116]. Tumor growth is closely correlated with cell proliferation and apoptosis. The clonal proliferation ability of PC9/GR cells was evaluated in a study on targeted drug resistance in NSCLC, and the data showed that the proliferation of PC9/GR cells decreased significantly after FGL1 silencing [114]. Knockout of FGL1 could significantly dampen the proliferation of SGC-7901 cells [94]. It has been reported that the activation of mTOR is tightly related to the proliferation of HCC cells [117]. As an inhibitor of HCC, FGL1 regulates the occurrence of $\mathrm{HCC}$ mainly by inhibiting $\mathrm{AKT}$ and downstream pathways, indicating that AKTmTOR is an important pathway downstream of FGL1 involved in regulating cell proliferation $[67,118]$. On the other hand, in the mechanism of FGL1-mediated gefitinib resistance, FGL1 was found to regulate apoptosis through the PARP1/caspase-3 pathway [114], which also confirmed that FGL1 is pertinent to the sensitivity of tumor cells to targeted EGFR-tyrosine kinase inhibitors (TKIs) (Fig. 2). A recent study on FGL1-mediated targeted therapy resistance have also been reported in HCC [116]. In addition, although FGL1 is a mediator of radiation injury [71-73], the correlation between FGL1 and radiation sensitivity needs to be confirmed by additional studies.

\section{FGL1 and tumor immune escape}

In the tumor microenvironment (TME), some tumor and regulatory immune cells, such as regulatory $\mathrm{T}$ cells (Tregs) [119-122], myeloid-derived suppressor cells (MDSCs) [123-128], tumor-associated macrophages (TAMs) [129-131], immature dendritic cells (iDCs) [132, 133] have the ability to generate inhibitory molecules (like TIM3 [134-136], TIGIT [137, 138] and VISTA [139]), which can bind receptors on immune cells (NK cells, lymphocytes, etc.), reducing the toxicity of immune responses and thus contributing to immune escape. These molecules play important roles in antitumor efficacy and outcome prediction. The most representative 


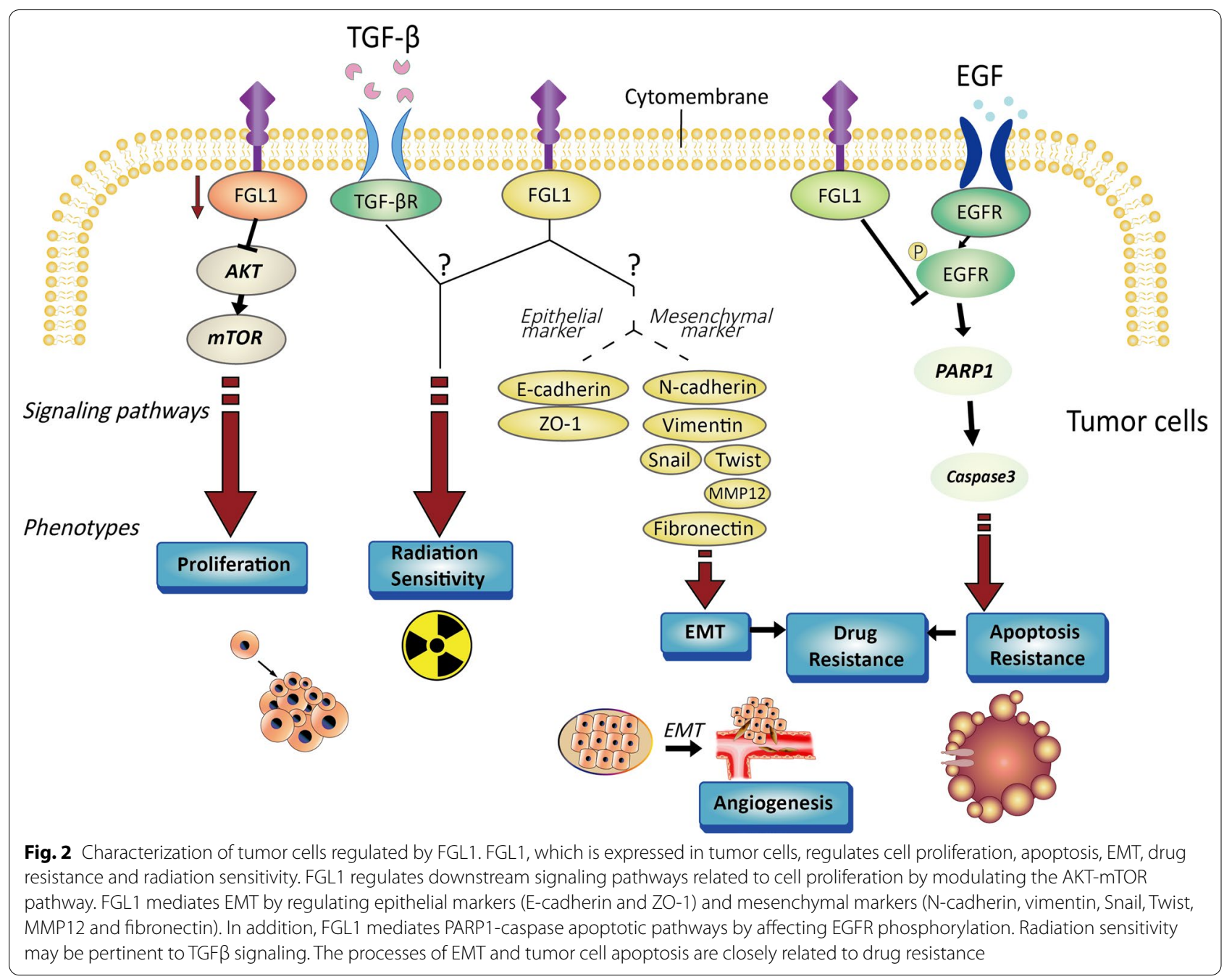

immune checkpoint targets are PD-1 $[4,11,140,141]$ and PD-L1 [82, 123, 128, 142-145]. More recently, Chen and his coworkers have elucidated that the FGL1/LAG3 pathway is another encouraging immune checkpoint pathway that plays a crucial role in the immune escape mechanism, similar to PD-1/PD-L1, and potentially mediates resistance to anti-PD-1/PD-L1 therapy. Thus, as a LAG3 ligand, FGL1 will be another promising biomarker with predictive value for PD-1/PD-L1 resistance [50].

\section{FGL1 is a major immune inhibitory ligand of LAG3}

FGL1 was first identified as a new high-affinity ligand for the inhibitory receptor LAG3 by Dr. Chen's team in 2019 [50]. LAG3 is a type I transmembrane protein that exists mainly on the surface of activated $\mathrm{T}$ cells (including $\mathrm{CD}^{+}$and $\mathrm{CD}^{+} \mathrm{T}$ cells and Tregs) [146-148], NK cells [149], plasmacytoid dendritic cells (pDCs), and so on. The extracellular domain of LAG3 is $20 \%$ similar to that of CD4 [12], which determines the high affinity between LAG3 and MHC II. LAG3 interacts with MHC II and generates a negative signal (blocking the TCR activation signal) to restrict $\mathrm{T}$ helper 1 (Th1) cell activation, proliferation and secretion $[150,151]$. Conversely, activated $\mathrm{T}$ cells expressing LAG3 stimulate the production of cytokines (tumor necrosis factor (TNF)- $\alpha$ and IL-12) in antigen-presenting cells (APCs) (DCs and monocytes) and induce their maturation and activation [152]. Notably, researchers found that junction peptides between the D4 transmembrane region and transmembrane region could be cleaved to generate soluble LAG3 (s-LAG3) [12, $153,154]$, which could activate thymic epithelial cells and increase $\mathrm{CD}^{+} \mathrm{T}$ cell levels through the transduction of MHC II signals (Fig. 3).

In some subsequent studies, it was confirmed that MHC II is not the only ligand of LAG3 [43]. Most recently, evidence has demonstrated that FGL1 is another type of high-affinity immunosuppressive ligand that binds to LAG3. A number of basic research studies have 


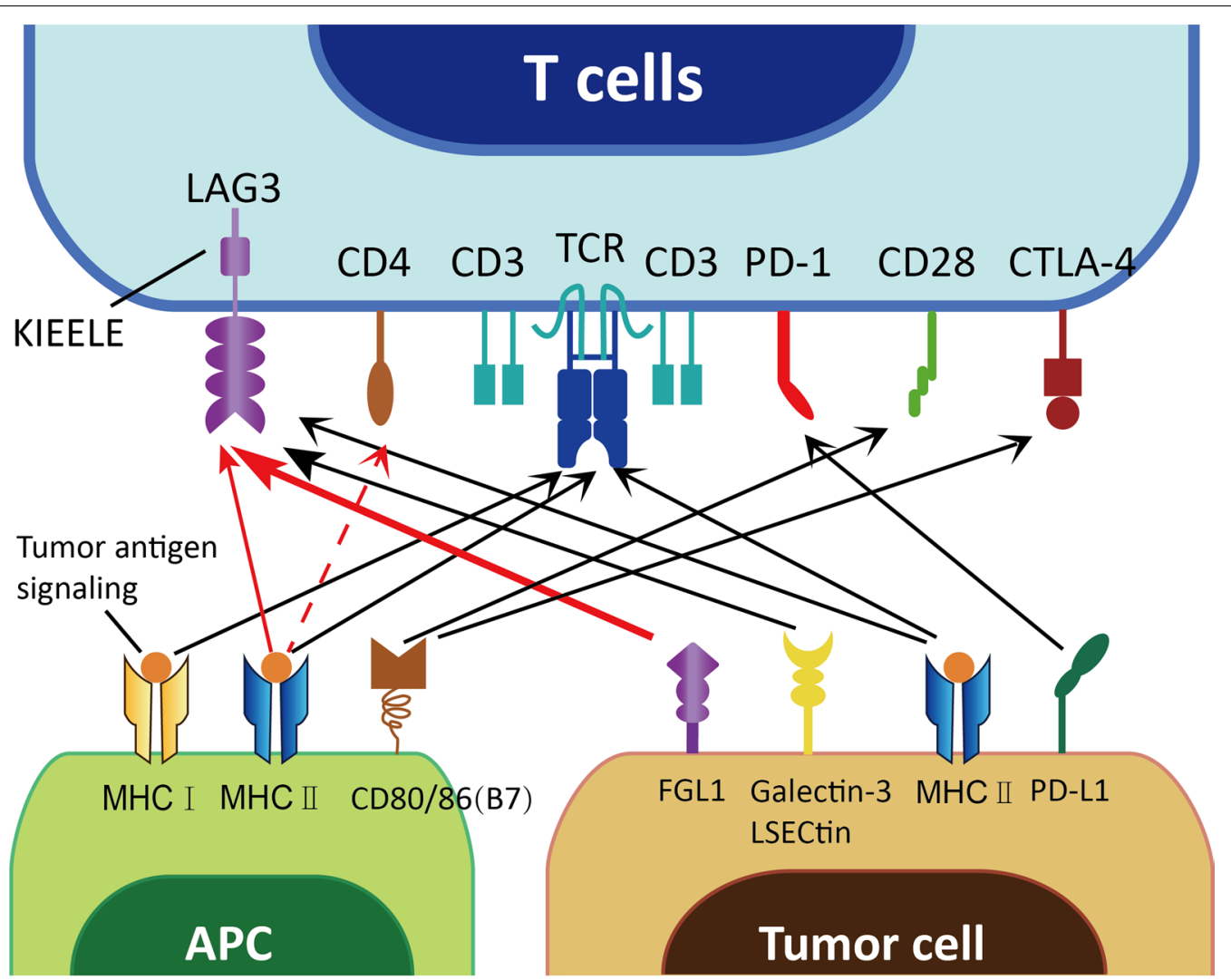

Fig. 3 Classic and novel immune checkpoints between tumor cells and immune cells. The traditional marker PD-L1 (B7-H1/CD274), expressed on the surface of tumor cells, binds to PD-1 on the T cell surface, while the newly identified molecule FGL1 binds to another inhibitory receptor, LAG3, which has other ligands, such as MHC II, galectin-3 and LSECtin (degree of affinity: thick line > thin line > dashed line). In addition, CD80 and CD86 (B7) on the surface of APCs bind with CD28 or CTLA-4 to provide auxiliary stimulatory and suppressive signals, respectively

revealed that there is a high-affinity interaction between LAG3 and FGL1 [13]. In the Genome-Scale Receptor Array (GSRA) system, FGL1 was the main binding protein of LAG3-Ig, and the interaction between them was stable, specific and conserved across species. A further domain deletion study showed that the fibrinogen-like domain (FD) in FGL1 and the D1-D2 domain in LAG3 are involved in the MHC II-independent interaction between FGL1 and LAG3. Based on in vivo experiments, loss of the FGL1/LAG3 interaction could be achieved by gene knockout or antibody blockade, and antitumor immunity could be promoted by stimulating tumor-infiltrating lymphocyte (TIL) activation and expansion in the TME [50].

\section{Synergistic inhibition of T cells with PD-1 and FGL1 as a LAG3 ligand}

Although the specific mechanism by which FGL1/LAG3 modulates $\mathrm{T}$ cell functions remains unclear, the synergistic inhibitory effect of FGL1 blockade in conjunction with anti-PD-1 therapy has been confirmed in animal models [50]. It has been indicated that blocking FGL1 can cooperate with anti-PD-1/PD-L1 therapy to suppress the effect of PD-1/PD-L1 signaling, which is based on previous basic research studies on the synergistic inhibitory activities [146, 153, 155-157]. The synergistic inhibitory effect of LAG3 and PD-1 on T cells has been confirmed in a variety of tumors, including NSCLC [158], melanoma [159], renal cell carcinoma (RCC) $[160,161]$, head and neck cancer [6], and breast cancer [162, 163]. Among these diseases, melanoma shows a close relationship between the coexpression of the immune checkpoint molecules LAG3 and PD-1 and the expression of CD163 and density of TAMs $[129,164]$. These preclinical results have paved the way for combinatorial blockade of PD-1 and LAG3 in clinical trials [165]. Most importantly, FGL1 will be a potential biomarker for predicting the outcome of PD-1/PD-L1 blockade therapy, since high plasma FGL1 levels were reported to be significantly correlated with a worse therapeutic response to anti-PD-1/ PD-L1 therapy in NSCLC and melanoma patients [50, 166]. Therefore, FGL1 can be identified as a next-generation cancer immunotherapy target capable of a functional 
interaction with the LAG3 pathway and synergistic inhibition of T cells with PD-1.

\section{FGL1/LAG3 is an immunosuppressive pathway independent of PD-1/PD-L1}

A series of immunological animal experiments have confirmed the synergistic effect of the inhibitory receptors LAG3 and PD-1 on T cells [146, 157]. However, the FGL1/LAG3 pathway also plays an immunosuppressive role independent of the PD-1/PD-L1 pathway. It is well known that the PD-1/PD-L1 inhibitory pathway produces exhausted T cells (Fig. 4a). Anti-PD-1/PD-L1 antibodies can block this immune brake and release the antitumor activity of $\mathrm{T}$ cells (Fig. 4b). However, due to the existence of another inhibitory receptor, LAG3, on the $T$ cell surface, another newly characterized immune checkpoint is generated when LAG3 interacts with its ligand FGL1 (Fig. 4c). It has been reported that blocking LAG-3 is more significant in T cell activation, proliferation and IFN- $\gamma$ secretion than blocking the PD-1 pathway [155]. Under tolerance conditions, signal transduction through the PD-1/PD-L1 and FGL1/LAG-3 pathways have different functional consequences for $\mathrm{CD}^{+} \mathrm{T}$ cell subsets; that is, external signaling initiation can affect the tolerance of $\mathrm{CD} 8^{+}$ $\mathrm{T}$ cell subsets through the LAG3 and PD-1 pathways [164]. The most direct manifestation upstream of these consequences is the production of three $\mathrm{CD} 8^{+} \mathrm{T}$ cell subsets with inconsistent expression and localization of LAG3 and PD-1. Further cytolytic functional analysis showed that the $\mathrm{T}$ cell subsets with high expression of LAG3 produced higher levels of cytokines, especially IFN- $\gamma$, TNF- $\alpha$ and CD107, than those with high expression of PD-1 but were not associated with the expression of the costimulatory molecules inducible $\mathrm{T}$ cell co-stimulator (ICOS) and 4-1BB (CD137) [164, 167169]. The differences in cytokine production patterns mentioned above indicate the independence of the two pathways. In addition, in animal experiments, more than $30 \%$ of MC38 tumor-bearing mice were found to have no tumor formation within 150 days of treatment with anti-FGL1/LAG3 as a monotherapy or in combination with anti-PD-1/PD-L1 therapy [50]. Because of the high affinity between FGL1 and LAG3, FGL1/LAG3 and PD-1/PD-L1 can regulate $\mathrm{T}$ cells independently, and blocking both these checkpoints can produce synergistic antitumor effects. However, the upregulation of LAG-3 expression in NSCLC is associated with insensitivity to PD-1 axis blockade and a poor prognosis [170], which suggests the independence of immune escape pathways and the potential of the synergistic action of anti-PD-1 and anti-LAG3 antibodies in clinical trials.

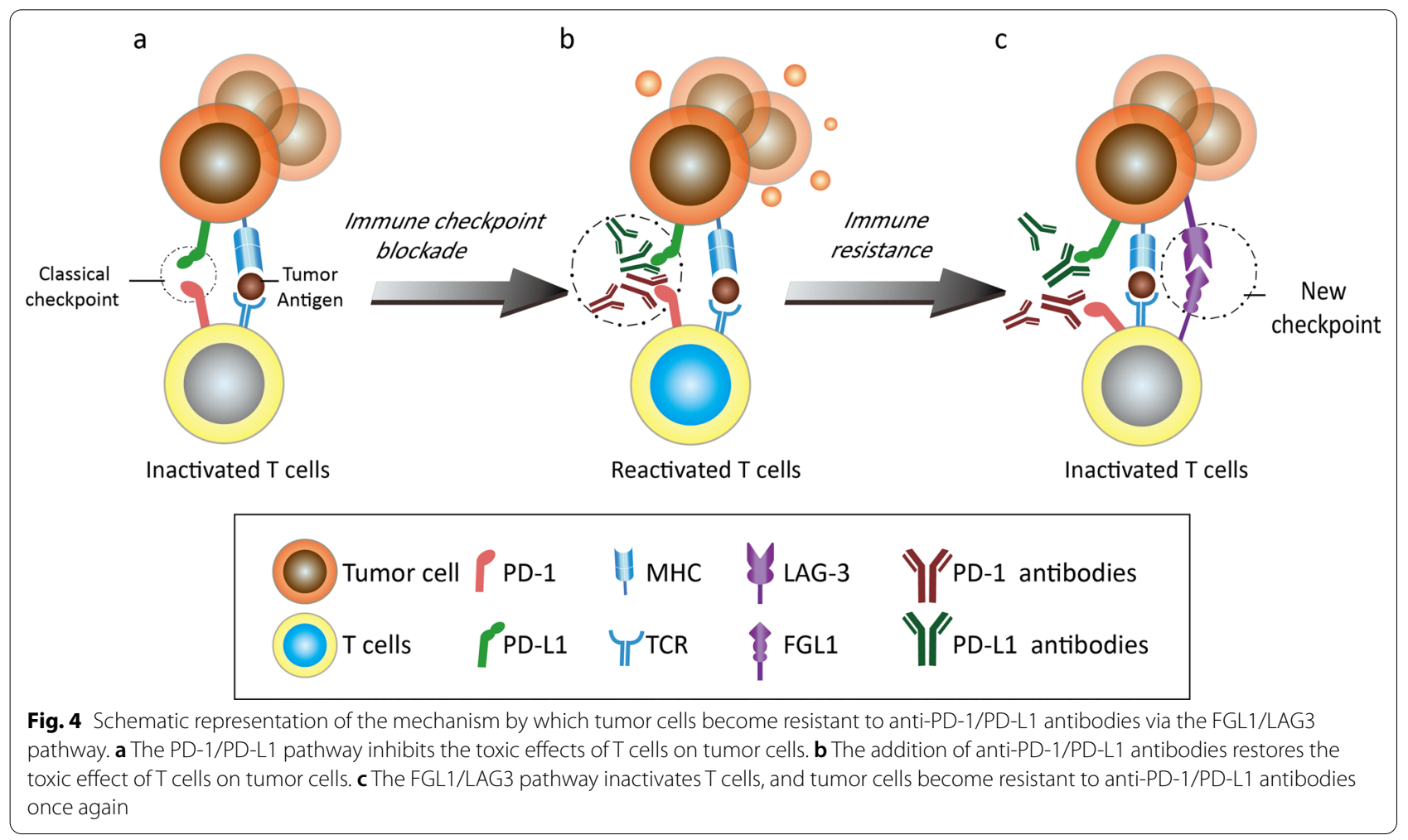




\section{Clinical prospects of anti-FGL1 in cancer therapy Anti-FGL1 may overcome immune checkpoint blockade resistance via a tumor-intrinsic mechanism}

Based on the above evidence that the FGL1/LAG3 pathway plays an important role in immune evasion during cancer development, anti-FGL1 may help overcome cancer immunotherapeutic resistance as a promising novel checkpoint. Characteristics that are necessary for the immune checkpoint inhibitor (ICI) response include IFN- $\gamma$ signaling, antigen-presenting signaling, immuneevasive oncogenic signaling, and a mutational signaling landscape $[171,172]$. It is well known that the $\mathrm{T}$ cell receptor (TCR) on the tumor-reactive $\mathrm{T}$ cell surface recognizes tumor neoantigens and subsequently releases IFN- $\gamma$, which binds to the IFN- $\gamma$ receptor (IFN- $\gamma$ R1/R2) on the tumor cell surface, activates downstream JAKSTAT signaling pathways and further initiates PD-L1 transcription in tumor cells [171, 173, 174]. The plasma level of IFN- $\gamma$ was reported to be obviously increased after the injection of $\mathrm{CD}^{+} \mathrm{OT}-1 \mathrm{~T}$ cells together with the FGL1 antibody 177R4 into syngeneic mice (Table 3), which further proves that the blockade of FGL1 by a monoclonal antibody stimulates $\mathrm{T}$ cell immunity in a manner similar to anti-LAG3 therapy [50]. Moreover, FGL1 is highly secreted from tumor cells, and higher plasma levels of FGL1 are associated with resistance to ICIs and poor prognosis in cancer patients [50]. Hence, using FGL1 agents can theoretically enhance the antitumor effect of $\mathrm{T}$ cells and thus affect the acquired resistance of ICIs in patients with differential levels of PD-L1 expression.

Furthermore, antigen presentation blockade is another intrinsic factor underlying ICI resistance, which is mainly caused by MHC deficiency and loss of tumor antigenicity $[175,176]$. MHC II is the first identified ligand of LAG3 [177]. However, their binding does not affect antitumor activity, suggesting that MHC II is not solely responsible for the function of LAG3. More valuable ligands presumably restart the "immune brake" by binding with LAG3. Therefore, as a newly discovered high-affinity ligand of LAG3, FGL1 has the potential to induce ICI resistance in a receptor-ligand interdependent manner [50]. Moreover, cancers with a high tumor mutation burden (TMB) and high neoantigen expression, such as melanoma and NSCLC, are generally more sensitive to immune checkpoint blockade [60, 173, 178]. However, these patients were observed to have higher plasma levels of FGL1 expression after the acquisition of ICI resistance [50]. Thus, the FGL1 secretion level in plasma is a potential biomarker for identifying patients who will not benefit from ICI treatment. Finally, Wnt/ $/$-catenin is an essential signaling pathway in cancer development $[179,180]$. Emerging evidence indicates that the Wnt $5 \alpha-\beta$-cateninPPAR $\gamma$ signaling pathway drives a metabolic program that triggers dendritic cell (DC) tolerance and immunotherapy resistance [181, 182]. PPAR $\gamma$ is the ultimate target of FGL1-induced lipid synthesis in adipocytes, suggesting that FGL1 has the potential to induce immunosuppression by regulating PPAR $\gamma$ synthesis in metabolic programs [56].

\section{Anti-FGL1 may overcome immune checkpoint blockade resistance via exogenous factors}

In addition to intrinsic factors, alterations in the functions and numbers of immune effector cells (mainly $\mathrm{CD}^{+} \mathrm{T}$ cells) in the tumor microenvironment (TME)

Table 3 Clinical and preclinical data related to anti-FGL1 therapy

\begin{tabular}{|c|c|c|c|c|c|c|}
\hline Number & Year & Type of tumor & Human/mouse/cell line & Name of FGL1 antibody & Conclusions & References \\
\hline 1 & 2021 & PDAC & Cell lines & FGL1 antibody, (Proteintech) & $\begin{array}{l}\text { Anti-FGL1 was associated with lipid } \\
\text { metabolism and cell growth in PDAC }\end{array}$ & {$[115]$} \\
\hline 2 & 2021 & $\mathrm{HCC}$ & Cell lines & FGL1 antibody, (Proteintech) & $\begin{array}{l}\text { Anti-FGL1 eliminated resistance to } \\
\text { sorafenib in HCC cells }\end{array}$ & {$[116]$} \\
\hline 3 & 2020 & NSCLC & Cell lines & ab197357 (Abcam) & $\begin{array}{l}\text { Anti-FGL1 increased the sensitivity of } \\
\text { NSCLC cells to gefitinib }\end{array}$ & {$[114]$} \\
\hline 4 & 2019 & $\begin{array}{l}\text { Murine colon } \\
\text { adenocarci- } \\
\text { noma }\end{array}$ & Cell lines and mouse model & Anti-mouse FGL1 (clone 177R4) & $\begin{array}{l}\text { Both anti-FGL1 and anti-LAG3 mAbs } \\
\text { significantly controlled the growth } \\
\text { of tumors derived from the MC } 38 \\
\text { murine colon that were inoculated } \\
\text { into syngeneic C } 57 \mathrm{BL} / 6 \text { mice }\end{array}$ & {$[50]$} \\
\hline 5 & 2019 & Murine liver cell & Cell lines and mouse model & & $\begin{array}{l}\text { Both anti-FGL1 and anti-LAG3 mAbs } \\
\text { significantly controlled the growth } \\
\text { of tumors derived from established } \\
\text { Hepa1-6 murine liver cell lines that } \\
\text { were inoculated into syngeneic } \\
\text { C57BL/6 mice }\end{array}$ & \\
\hline
\end{tabular}


are challenging for immunotherapies [183]. Various immune cells (DCs, Tregs, myeloid-derived suppressor cells (MDSCs)) and their related secretory products and metabolites in the TME play essential roles in tumor development, metastasis and immunotherapeutic response [184]. Persistent antigen exposure in the TME clearly results in sustained LAG3 expression, thereby having a substantial effect on the immunosuppression status and cytokine production. As a major LAG3 functional ligand independent of MHC-II, FGL1 is positively correlated with MDSC and Treg populations and negatively correlated with $\mathrm{CD} 8^{+} \mathrm{T}$ cells as determined by analysis of the TIMER database (http://timer.cistrome. org/). The regulatory effect of FGL1 on the TME was further demonstrated in a breast cancer model constructed using biomimetic nanomaterials designed to deliver a short interfering RNA targeting FGL1 [185]. Moreover, FGL1 was shown to be closely associated with tumor cell invasion and metastasis via acquisition of the EMT phenotype, which was underlined by bidirectional crosstalk between tumor cells and the surrounding TME [93,
94]. This evidence indicates preferential suppression of $\mathrm{T}$ cell immunity in the TME upon FGL1-LAG3 signaling. Indeed, the current insights into the mechanism by which FGL1 induces immunotherapy resistance via immunosuppression of the TME are relatively limited, and more in-depth investigations are still needed (Fig. 5).

\section{Potential toxicity patterns of anti-FGL1 therapy}

Based on clinical trials and medical practices, ICI therapies not only initiate the activation of an anticancer immune response but also cause a wide range of immune-related adverse events (irAEs), and the costs of immunotherapies continue to increase due to the diversity of $\mathrm{T}$ cell expansion and cell infiltration [186]. Different from the toxic effects of traditional chemotherapy, the most frequently affected organs are the skin, digestive system (gastrointestinal, liver) and endocrine system, with symptoms of nausea, diarrhea, pruritus, rashes and thyroid problems, and fatal irAEs include myocarditis, pneumonia, hepatitis and meningitis [187]. The frequency of irAEs and potential

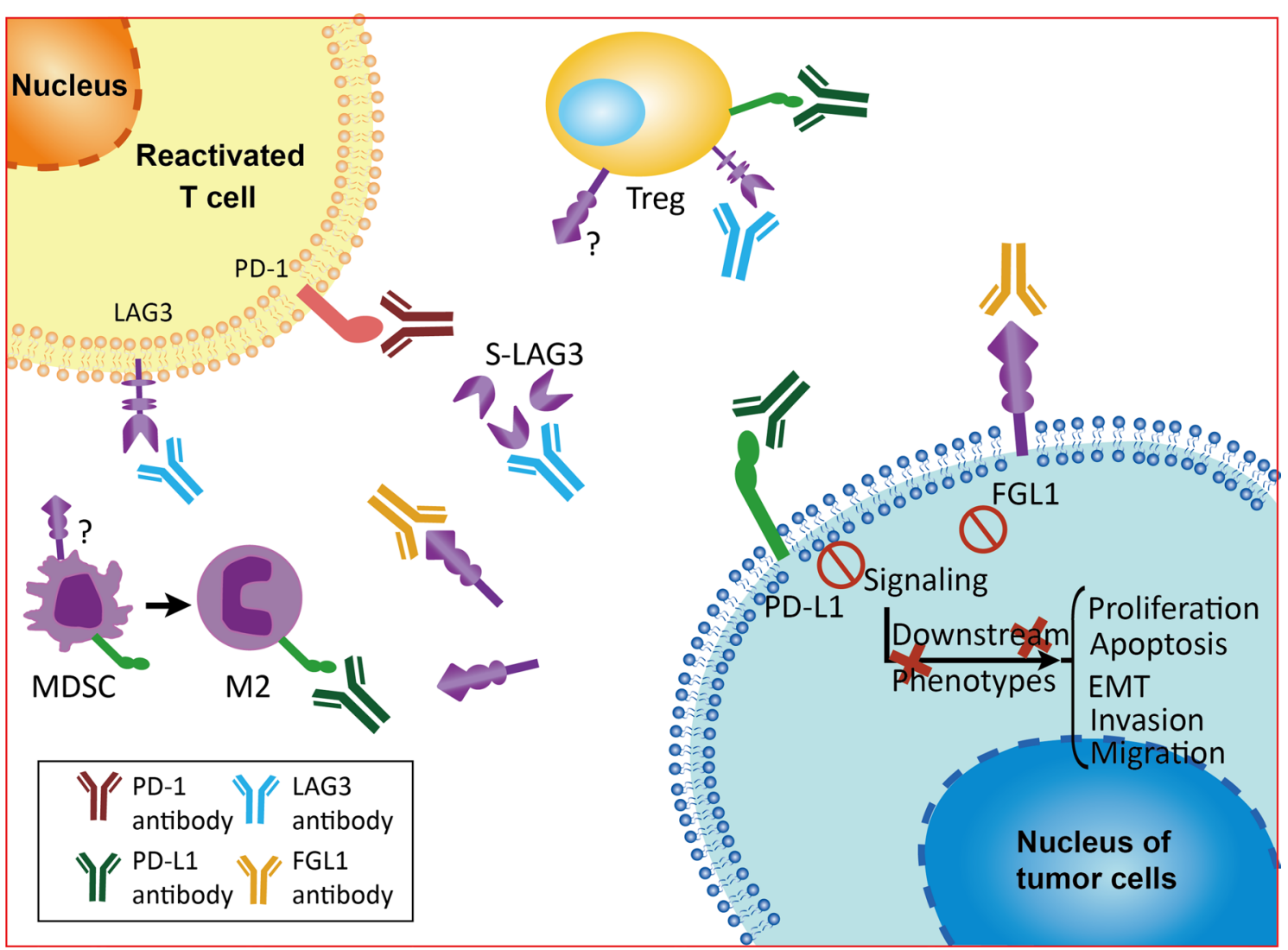

Fig. 5 Combined use of antibodies targeting PD-1/PD-L1 and FGL1/LAG3 in the tumor microenvironment. The PD-1/P-L1 and FGL1/LAG3 signaling pathways can be inhibited by the corresponding antibodies, leading to the reactivation of nonactive $T$ cells, while downstream pathways and phenotypes associated with tumor cell progression are weakened. In addition to TILs, MDSCs, TAMs (M2) and Tregs in the TME are known to mediate antitumor immunity through the PD-1/PD-L1 pathway, but their roles in the FGL1/LAG3 pathway remain to be determined 
Table 4 Summary of clinical trials utilizing agents targeting LAG3 alone or in combination with others

\begin{tabular}{|c|c|c|c|c|c|c|c|}
\hline Drug & $\begin{array}{l}\text { Clinical trial } \\
\text { number }\end{array}$ & Phase & Status & Tumor type & Clinical efficacy & Safety & Details \\
\hline \multirow[t]{4}{*}{$\begin{array}{l}\text { MGD013 (tebote- } \\
\text { limab) }\end{array}$} & NCT04212221 & $|/| \mid$ & Recruiting & $\mathrm{HCC}$ & NA & NA & $\begin{array}{l}\text { In combination with } \\
\text { brivanib alaninate } \\
\text { (ZL-2301) }\end{array}$ \\
\hline & NCT04653038 & । & Recruiting & Melanoma & NA & NA & Single agent \\
\hline & NCT04634825 & $\|$ & Recruiting & HNSCC & NA & NA & $\begin{array}{l}\text { Tebotelimab or } \\
\text { retifanlimab (PD-1 } \\
\text { antibody) plus eno- } \\
\text { blituzumab (B7-H3 } \\
\text { antibody) }\end{array}$ \\
\hline & NCT03219268 & & $\begin{array}{l}\text { Active, not recruit- } \\
\text { ing }\end{array}$ & $\begin{array}{l}\text { Neoplasms } \\
\text { (unresectable or } \\
\text { metastatic) }\end{array}$ & NA & $\begin{array}{l}\text { Fatigue: } 19 \% \\
\text { Nausea: } 11 \% \\
\text { Grade } \geq 3 \text { TRAEs: } \\
23.2 \%\end{array}$ & $\begin{array}{l}\text { irAEs were consist- } \\
\text { ent with events } \\
\text { observed in anti- } \\
\text { PD-1 antibodies }\end{array}$ \\
\hline $\begin{array}{l}\text { BMS-986016 } \\
\text { (relatlimab) }\end{array}$ & NCT03470922 & $\|/\| I \|$ & $\begin{array}{l}\text { Active, not recruit- } \\
\text { ing }\end{array}$ & $\begin{array}{l}\text { Melanoma } \\
\text { (unresectable or } \\
\text { metastatic) }\end{array}$ & NA & NA & $\begin{array}{l}\text { In combination with } \\
\text { nivolumab (anti- } \\
\text { PD-1 mAb) }\end{array}$ \\
\hline $\begin{array}{l}\text { REGN3767 (fian- } \\
\text { limab) }\end{array}$ & NCT03005782 & I & Recruiting & Malignancies & $\begin{array}{l}\text { ORR: } 64 \% \text { ( } 21 \\
\text { of } 33 \text { patients; } \\
3 \text { complete } \\
\text { responses, } 18 \text { par- } \\
\text { tial responses) }\end{array}$ & $\begin{array}{l}\text { Monotherapy } \\
\text { TRAE } \\
\text { Nausea: } 22.2 \% \\
\text { Increased ALT and } \\
\text { AST: } 3.7 \% \\
\text { Combination } \\
\text { therapy TRAE } \\
\text { Fatigue: } 31 \% \\
\text { Rash: } 23 \% \\
\text { Grade } \geq 3 \text { irAEs: } \\
\text { Hypothyroidism: } \\
\text { 2.4\% }\end{array}$ & $\begin{array}{l}\text { In combination } \\
\text { with Cemiplimab } \\
\text { (REGN2801) }\end{array}$ \\
\hline Bl 754111 & $\begin{array}{l}\text { NCT03156114 } \\
\text { NCT03433898 } \\
\text { NCT03697304 } \\
\text { NCT03780725 }\end{array}$ & $|/| \mid$ & $\begin{array}{l}\text { Active, not recruit- } \\
\text { ing/ } \\
\text { Recruiting/ } \\
\text { completed }\end{array}$ & $\begin{array}{l}\text { Carcinoma, } \\
\text { NSCLC, } \\
\text { Head and neck } \\
\text { neoplasms }\end{array}$ & NA & $\begin{array}{l}\text { Any AEs: } 86.7 \% ; \\
\text { Any irAEs: } 21.1 \% \\
\text { IRRs: } 4.9 \% \\
\text { Hypothyroidism: } \\
3.2 \%\end{array}$ & $\begin{array}{l}\text { In combination with } \\
754091 \text { (anti-PD-1 } \\
\text { mAb) }\end{array}$ \\
\hline \multirow[t]{2}{*}{$\begin{array}{l}\text { IMP321 (eftilagi- } \\
\text { mod alpha) }\end{array}$} & NCT02676869 & I & Completed & $\begin{array}{l}\text { Stage IV/III mela- } \\
\text { noma }\end{array}$ & ORR: 33-50\% & $\begin{array}{l}\text { No dose-limiting } \\
\text { toxicities } \\
\text { Main AE: IRR }\end{array}$ & $\begin{array}{l}\text { In combination with } \\
\text { pembrolizumab } \\
\text { (anti-PD-1 mAb) }\end{array}$ \\
\hline & NCT03625323 & $\|$ & Recruiting & $\begin{array}{l}\text { NSCLC } \\
\text { HNSCC }\end{array}$ & NA & NA & \\
\hline $\begin{array}{l}\text { BMS-986213 } \\
\text { (relatlimab, } \\
\text { nivolumab) }\end{array}$ & NCT03662659 & $\|$ & $\begin{array}{l}\text { Active, not recruit- } \\
\text { ing }\end{array}$ & GC/GEJC & NA & NA & $\begin{array}{l}\text { Relatlimab/ } \\
\text { nivolumab, given in } \\
\text { combination with } \\
\text { chemotherapy }\end{array}$ \\
\hline $\begin{array}{l}\text { BMS-986016 } \\
\text { (relatlimab) }\end{array}$ & NCT03607890 & $\|$ & Recruiting & MSI-H tumors & NA & NA & $\begin{array}{l}\text { Utilized in patients } \\
\text { with MSI-H solid } \\
\text { tumors refractory } \\
\text { to prior PD-(L)1 } \\
\text { therapy }\end{array}$ \\
\hline $\begin{array}{l}\text { LAG525 } \\
\text { (IMP701) }\end{array}$ & NCT03365791 & $\|$ & Completed & $\begin{array}{l}\text { Advanced solid } \\
\text { and hematologic } \\
\text { malignancies }\end{array}$ & NA & $\begin{array}{l}\text { AEs: } 98.7 \% \\
\text { Fatigue: } 36.84 \% \\
\text { Nausea: } 34.21 \% \\
\text { SAEs: } 42.1 \% \\
\text { Pneumonia: } \\
6.58 \%\end{array}$ & $\begin{array}{l}\text { In combination with } \\
\text { spartalizumab } \\
\text { (PDR001) (anti-PD-1 } \\
\text { mAb) }\end{array}$ \\
\hline Sym022 & NCT0331141 & I & Recruiting & $\begin{array}{l}\text { Metastatic cancer } \\
\text { solid tumors } \\
\text { lymphoma }\end{array}$ & NA & $\begin{array}{l}\text { Grade } \geq 3 \text { TRAEs: } \\
\text { Increased CPK: } \\
\text { 10\% } \\
\text { Decreased } \\
\text { lymphocytes: 5\% } \\
\text { Hypophysitis: } 5 \%\end{array}$ & $\begin{array}{l}\text { In combination with } \\
\text { Sym021 (anti-PD-1) } \\
\text { or Sym023 (anti- } \\
\text { TIM3) }\end{array}$ \\
\hline
\end{tabular}


Table 4 (continued)

\begin{tabular}{|c|c|c|c|c|c|c|c|}
\hline Drug & $\begin{array}{l}\text { Clinical trial } \\
\text { number }\end{array}$ & Phase & Status & Tumor type & Clinical efficacy & Safety & Details \\
\hline LBL-007 & NCT04640545 & I & Recruiting & $\begin{array}{l}\text { Advanced mela- } \\
\text { noma }\end{array}$ & NA & NA & $\begin{array}{l}\text { In combination with } \\
\text { toripalimab (anti- } \\
\text { PD-1 mAb) }\end{array}$ \\
\hline FS0118 & NCT03440437 & $|/| \mid$ & Recruiting & $\begin{array}{l}\text { Advanced malig- } \\
\text { nancies }\end{array}$ & NA & NA & Single agent \\
\hline TSR-033 & NCT03250832 & I & $\begin{array}{l}\text { Active, not recruit- } \\
\text { ing }\end{array}$ & Neoplasms & NA & NA & $\begin{array}{l}\text { TSR-033/dostar- } \\
\text { limab (anti-PD-1 } \\
\text { mAb) in combina- } \\
\text { tion with chemo- } \\
\text { therapy }\end{array}$ \\
\hline
\end{tabular}

ALT: alanine aminotransferases; AST: aspartate aminotransferases; MSI-H: high levels of microsatellite instability; GEJC: esophagogastric junction cancer; HNSCC: head and neck squamous cell carcinoma; irAE: immune-related adverse event; IRR: infusion-related reaction; NA: not available; ORR: objective response rate; TRAE: treatment-related adverse event; SAE: severe adverse event; mAb: monoclonal antibody

toxicity patterns are dependent on the immunotherapy strategy, exposure time, medicinal dose administered and individual intrinsic risk factors of the patient [186].

Some novel emerging immune checkpoints are approved for clinical trials in combination with CTLA-4 or PD-1(L1) blockade, such as anti-LAG-3, which increases the probability and new descriptions of irAEs (Table 4). Multiple new agents have been identified as targeting LAG3 across various tumors [188]. The most common agent-related AEs, fatigue and nausea, are well tolerated. Nonetheless, the discovery of more novel checkpoints is still urgently needed in the paradigm of cancer treatment. Among the potential candidates, FGL1 has promise despite that it remains in the preclinical stage, and researchers are awaiting more advanced data. Theoretically, as another ligand of LAG3 in addition to the canonical ligand MHC-II, FGL1 may have more advantages than anti-LAG3 in regards to irAEs. Future studies should also optimize the selection of new ICIs by screening potential predictive biomarkers for the irAE risks [189].

\section{Future directions of anti-FGL1 in cancer therapy}

Despite the early stage of tumor research, FGL1 is a new immune checkpoint molecule that is thought to have a promising future in clinical applications, especially in NSCLC immunotherapy [190-193], which is attributed to its overexpression in NSCLC cells and close correlations with immune regulation, tumor neovascularization [194], EMT progression [195], resistance and metastasis $[116,196,197]$. The novel discovery of a high-affinity interaction between FGL1 and LAG3 in immunology marks a major breakthrough in research on immune checkpoint blockade therapy.
This strategy holds great potential as a third-generation immune checkpoint blockade after targeting CTLA-4 and PD-1/PD-L1 [198]. Currently, multiple clinical trials evaluating the synergistic effects of anti-LAG3 and anti-PD-1 antibodies are ongoing, and significant efficacy has been achieved in completed trials on melanoma (stage III/IV), metastatic breast cancer and RCC (stage IV) [163, 165]. Although the number of ongoing clinical trials targeting FGL1 are not sufficient, a significant positive correlation between FGL1 expression and long-term prognosis has been observed for patients with multiple types of metastatic cancer who are treated with anti-PD-1/PD-L1 therapy (Table 2). Based on the above results, patients with advancedstage tumors reliant on ICIs are likely to benefit from anti-FGL1 therapy. More prospective clinical trials targeting FGL1 alone or in combination with other ICI agents are needed to facilitate translocation from bench to bedside.

\section{Conclusions}

As an acute inflammatory factor secreted by the liver, FGL1 is upregulated in various solid tumors and associated with the EMT, proliferation, apoptosis and drug resistance of tumors as well as with poor prognosis. Most importantly, an immunosuppressive pathway distinct from that of PD-1/PD-L1 forms between FGL1 and the inhibitory receptor LAG3. Targeting FGL1 acts on both tumor cells themselves and immune cells, which exerts a two-way synergistic effect on advanced cancers through a targeted therapeutic strategy. Therefore, FGL1 demonstrates significant advantages as a biomarker for predicting the efficacy of anti-PD-1/ PD-L1 therapy in patients with advanced tumors, and 
targeting FGL1 has promise as another promising immune checkpoint blockade strategy in clinical trials. Novel therapeutic strategies targeting FGL1 should be further explored in the treatment of cancer.

\begin{abstract}
Abbreviations
AP-1: Activating protein-1; CD107/137/ 163/223/274: Cluster of Differentiation 107/137/163/223/274; C/EBPß: CCAAT/enhancer-binding protein $\beta$; CTC : Circulating tumor cell; DC: Dendritic cell; EGFR: Epidermal growth factor receptor; ERK: Extracellular regulated protein kinases; FGL1: Fibrinogen-like protein 1; HNF-1 a: Hepatocyte nuclear factor-1a; ICOS: Inducible T cell costimulator; irRC: Immune-related response criteria; IL-6/12: Interleukin-6/12; IFN-ү: Interferon-ү; JNK: Jun N-terminal kinase; LKB1: Liver kinase B1; LAG3: Lymphocyte activation gene 3; MMP: Matrix metalloprotease; mAb: Monoclonal antibody; mTOR: Mammalian target of rapamycin; NK: Natural killer; NRF2: Nuclear factor erythroid-2-related factor 2; NSCLC: Non-small cell lung cancer; PD-1: Programmed cell death protein 1; pDC: Plasmacytoid dendritic cell; PDL1: Programmed cell death ligand 1; PPARY: Peroxisome proliferator-activated receptor gamma; RA: Rheumatoid arthritis; SOD1: Superoxide dismutase 1; STAT3: Signal transducer and activator of transcription 3; TCGA: The cancer genome atlas; TCR: T cell receptor; TGF- $\beta$ : Transforming growth factor- $\beta$; TIGIT:T cell immunoreceptor with Ig and ITIM domains; TIL: Tumor-infiltrating Iymphocyte; TIM3:T cell immunoglobulin domain and mucin domain-3; TKI: Tyrosine kinase inhibitor; TMB: Tumor mutation burden; TNF-a: Tumor necrosis factor-a; VISTA: V-domain Ig-containing Suppressor of T cell Activation; ZO-1: Zonula occludens-1.
\end{abstract}

\section{Acknowledgements}

Not applicable.

\section{Authors' contributions}

WQ performed the selection of literature, drafted the manuscript, and prepared the Figs. RW and MZ helped to collect literatures, participate in the discussion and revise the manuscript. HL carried out the design of this review and revised the manuscript. All authors contributed to this manuscript. All authors read and approved the final manuscript.

\section{Funding}

Not applicable.

\section{Availability of data and materials}

Data sharing not applicable to this article as no datasets were generated or analyzed during the current study.

\section{Declarations}

\section{Ethics approval and consent to participate}

Not applicable.

\section{Consent for publication}

Not applicable.

\section{Competing interests}

The authors declare that they have no competing interests.

\begin{abstract}
Author details
${ }^{1}$ Department of Oncology, Affiliated Zhongshan Hospital of Dalian University, No. 6 Jiefang Street, Dalian, Liaoning 110006, People's Republic of China. ${ }^{2}$ The Key Laboratory of Biomarker High Throughput Screening and Target Translation of Breast and Gastrointestinal Tumor, Dalian 116001, People's Republic of China. ${ }^{3}$ Department of Medical Oncology, the First Hospital of China Medical University, No.155 Nanjingbei Road, Shenyang, Liaoning 110001, People's Republic of China.
\end{abstract}

Received: 28 June 2021 Accepted: 1 September 2021 Published online: 15 September 2021

\section{References}

1. Wilky BA. Immune checkpoint inhibitors: the linchpins of modern immunotherapy. Immunol Rev. 2019;290:6-23.

2. Gambichler T, Reuther J, Scheel CH, Becker JC. On the use of immune checkpoint inhibitors in patients with viral infections including COVID19. J Immunother Cancer. 2020;8.

3. Zong Z, Wei Y, Ren J, Zhang L, Zhou F. The intersection of COVID-19 and cancer: signaling pathways and treatment implications. Mol Cancer. 2021:20:76.

4. Staron MM, Gray SM, Marshall HD, Parish IA, Chen JH, Perry CJ, et al. The transcription factor FoxO1 sustains expression of the inhibitory receptor PD-1 and survival of antiviral CD8(+) T cells during chronic infection. Immunity. 2014;41:802-14.

5. Boussiotis VA. Molecular and biochemical aspects of the PD-1 checkpoint pathway. N Engl J Med. 2016;375:1767-78.

6. Kok VC. Current understanding of the mechanisms underlying immune evasion From PD-1/PD-L1 immune checkpoint blockade in head and neck cancer. Front Oncol. 2020;10:268.

7. Patel SA, Minn AJ. Combination cancer therapy with immune checkpoint blockade: mechanisms and strategies. Immunity. 2018:48:417-33.

8. Topalian SL, Taube JM, Anders RA, Pardoll DM. Mechanism-driven biomarkers to guide immune checkpoint blockade in cancer therapy. Nat Rev Cancer. 2016;16:275-87.

9. Blackburn SD, Shin H, Haining WN, Zou T, Workman CJ, Polley A, et al. Coregulation of CD8 $+\mathrm{T}$ cell exhaustion by multiple inhibitory receptors during chronic viral infection. Nat Immunol. 2009;10:29-37.

10. Hui E, Cheung J, Zhu J, Su X, Taylor MJ, Wallweber HA, et al. T cell costimulatory receptor CD28 is a primary target for PD-1-mediated inhibition. Science. 2017;355:1428-33.

11. Kao C, Oestreich KJ, Paley MA, Crawford A, Angelosanto JM, Ali MA, et al. Transcription factor T-bet represses expression of the inhibitory receptor PD-1 and sustains virus-specific CD8+T cell responses during chronic infection. Nat Immunol. 2011;12:663-71.

12. Qin $S, X u L$, Yi M, Yu S, Wu K, Luo S. Novel immune checkpoint targets: moving beyond PD-1 and CTLA-4. Mol Cancer. 2019;18:155.

13. Parry RV, Chemnitz JM, Frauwirth KA, Lanfranco AR, Braunstein I, Kobayashi SV, et al. CTLA-4 and PD-1 receptors inhibit T-cell activation by distinct mechanisms. Mol Cell Biol. 2005;25:9543-53.

14. Zou W, Wolchok JD, Chen L. PD-L1 (B7-H1) and PD-1 pathway blockade for cancer therapy: mechanisms, response biomarkers, and combinations. Sci Transl Med. 2016;8:328rv4.

15. Kurra V, Sullivan RJ, Gainor JF, Hodi FS, Gandhi L, Sadow CA, et al. Pseudoprogression in cancer immunotherapy: rates, time course and patient outcomes. J Clin Oncol. 2016;34:6580-680.

16. Groisberg R, Hong DS, Behrang A, Hess K, Janku F, Piha-Paul S, et al. Characteristics and outcomes of patients with advanced sarcoma enrolled in early phase immunotherapy trials. J Immunother Cancer. 2017;5:100.

17. Champiat S, Dercle L, Ammari S, Massard C, Hollebecque A, PostelVinay $S$, et al. Hyperprogressive disease is a new pattern of progression in cancer patients treated by anti-PD-1/PD-L1. Clin Cancer Res. 2017;23:1920-8.

18. Kato S, Goodman A, Walavalkar V, Barkauskas DA, Sharabi A, Kurzrock R. Hyperprogressors after immunotherapy: analysis of genomic alterations associated with accelerated growth rate. Clin Cancer Res. 2017;23:4242-50

19. Saada-Bouzid E, Defaucheux C, Karabajakian A, Coloma VP, Servois V, Paoletti $X$, et al. Hyperprogression during anti-PD-1/PD-L1 therapy in patients with recurrent and/or metastatic head and neck squamous cell carcinoma. Ann Oncol. 2017;28:1605-11.

20. Wang $X$, Wang F, Zhong M, Yarden Y, Fu L. The biomarkers of hyperprogressive disease in PD-1/PD-L1 blockage therapy. Mol Cancer. 2020;19:81.

21. Rizvi NA, Antonia SJ, Shepherd FA, Chow LQ, Goldman J, Shen Y, et al. Nivolumab (Anti-PD-1; BMS-936558, ONO-4538) maintenance as monotherapy or in combination with bevacizumab (BEV) for nonsmall cell lung cancer (NSCLC) previously treated with chemotherapy. Int J Radiat Oncol Biol Phys. 2014;90.

22. Postow MA, Sidlow R, Hellmann MD. Immune-related adverse events associated with immune checkpoint blockade. 2018;378:158-68. 
23. Khan Z, Hammer C, Guardino E, Chandler GS, Albert ML. Mechanisms of immune-related adverse events associated with immune checkpoint blockade: using germline genetics to develop a personalized approach. Genome Med. 2019;11:39.

24. Li Y, Kang X, Wang H, Guo X, Zhou J, Duan L, et al. Clinical diagnosis and treatment of immune checkpoint inhibitor-associated adverse events in the digestive system. Thorac Cancer. 2020;11:829-34.

25. Herbst RS, Soria JC, Kowanetz M, Fine GD, Hamid O, Gordon MS, et al. Predictive correlates of response to the anti-PD-L1 antibody MPDL3280A in cancer patients. Nature. 2014;515:563-7.

26. Andrews LP, Marciscano AE, Drake CG, Vignali DA. LAG3 (CD223) as a cancer immunotherapy target. Immunol Rev. 2017;276:80-96.

27. Shergold AL, Millar R, Nibbs RJB. Understanding and overcoming the resistance of cancer to PD-1/PD-L1 blockade. Pharmacol Res. 2019;145:104258

28. Jerby-Arnon L, Shah P, Cuoco MS, Rodman C, Su MJ, Melms JC, et al. A Cancer cell program promotes T cell exclusion and resistance to checkpoint blockade. Cell. 2018;175:984-97.

29. Chen L, Diao L, Yang Y, Yi X, Rodriguez BL, Li Y, et al. CD38-mediated immunosuppression as a mechanism of tumor cell escape from PD-1/PD-L1 blockade. Cancer Discov. 2018;8:1156-75.

30. Dosset M, Vargas TR, Lagrange A, Boidot R, Vegran F, Roussey A, et al. PD-1/PD-L1 pathway: an adaptive immune resistance mechanism to immunogenic chemotherapy in colorectal cancer. Oncoimmunology. 2018;7:e1433981.

31. Nowicki TS, Hu-Lieskovan S, Ribas A. Mechanisms of resistance to PD-1 and PD-L1 blockade. Cancer J. 2018;24:47-53.

32. Wang $\mathrm{Q}$, Wu X. Primary and acquired resistance to PD-1/PD-L1 blockade in cancer treatment. Int Immunopharmacol. 2017;46:210-9.

33. Sharma P, Hu-Lieskovan S, Wargo JA, Ribas A. Primary, adaptive, and acquired resistance to cancer immunotherapy. Cell. 2017;168:707-23.

34. Shin DS, Zaretsky JM, Escuin-Ordinas H, Garcia-Diaz A, Hu-Lieskovan S, Kalbasi A, et al. Primary resistance to PD-1 blockade mediated by JAK1/2 mutations. Cancer Discov. 2017;7:188-201.

35. Tumeh PC, Harview CL, Yearley JH, Shintaku IP, Taylor EJ, Robert $L$, et al. PD-1 blockade induces responses by inhibiting adaptive immune resistance. Nature. 2014;515:568-71.

36. Mittal D, Vijayan D, Smyth MJ. Overcoming acquired PD-1/PD-L1 resistance with CD38 blockade. Cancer Discov. 2018;8:1066-8.

37. Jenkins RW, Barbie DA, Flaherty KT. Mechanisms of resistance to immune checkpoint inhibitors. Br J Cancer. 2018;1 18:9-16.

38. Masucci GV, Cesano A, Eggermont A, Fox BA, Wang E, Marincola FM, et al. The need for a network to establish and validate predictive biomarkers in cancer immunotherapy. J Transl Med. 2017;15:223.

39. Sun JY, Zhang D, Wu S, Xu M, Zhou X, Lu XJ, et al. Resistance to PD-1/ PD-L1 blockade cancer immunotherapy: mechanisms, predictive factors, and future perspectives. Biomark Res. 2020;8:35.

40. Mintz MA, Felce JH, Chou MY, Mayya V, Xu Y, Shui JW, et al. The HVEMBTLA axis restrains $T$ cell help to germinal center $B$ cells and functions as a cell-extrinsic suppressor in lymphomagenesis. Immunity. 2019:51:310-23.

41. Marin-Acevedo JA, Dholaria B, Soyano AE, Knutson KL, Chumsri S, Lou Y. Next generation of immune checkpoint therapy in cancer: new developments and challenges. J Hematol Oncol. 2018;11.

42. Ruffo E, Wu RC, Bruno TC, Workman CJ, Vignali DAA. Lymphocyteactivation gene 3 (LAG3): the next immune checkpoint receptor. Semin Immunol. 2019;42:101305.

43. Maruhashi T, Sugiura D, Okazaki IM, Okazaki T. LAG-3: from molecular functions to clinical applications. J Immunother Cancer. 2020;8.

44. Lino AC, Dang VD, Lampropoulou V, Welle A, Joedicke J, Pohar J, et al. LAG-3 inhibitory receptor expression identifies immunosuppressive natural regulatory plasma cells. Immunity. 2018;49:120-33 e9.

45. Gong J, Chehrazi-Raffle A, Reddi S, Salgia R. Development of PD-1 and PD-L1 inhibitors as a form of cancer immunotherapy: a comprehensive review of registration trials and future considerations. J Immunother Cancer. 2018;6:8.

46. Ohaegbulam KC, Assal A, Lazar-Molnar E, Yao Y, Zang X. Human cancer immunotherapy with antibodies to the PD-1 and PD-L 1 pathway. Trends Mol Med. 2015;21:24-33.
47. Marty Pyke R, Thompson WK, Salem RM, Font-Burgada J, Zanetti M, Carter $\mathrm{H}$. Evolutionary pressure against MHC class II binding cancer mutations. Cell. 2018;175:416-28 e13.

48. Johnson AM, Bullock BL, Neuwelt AJ, Poczobutt JM, Kaspar RE, Li HY, et al. Cancer cell-intrinsic expression of $\mathrm{MHC}$ class II regulates the immune microenvironment and response to anti-PD-1 therapy in lung adenocarcinoma. J Immunol. 2020;204:2295-307.

49. Newlaczyl AU, Yu LG. Galectin-3-a jack-of-all-trades in cancer. Cancer Lett. 2011;313:123-8.

50. Wang J, Sanmamed MF, Datar I, Su TT, Ji L, Sun J, et al. Fibrinogenlike protein 1 is a major immune inhibitory ligand of LAG-3. Cell. 2019;176:334-47.

51. Yan J, Yu Y, Wang N, Chang Y, Ying H, Liu W, et al. LFIRE-1/HFREP-1, a liver-specific gene, is frequently downregulated and has growth suppressor activity in hepatocellular carcinoma. Oncogene. 2004;23:1939-49.

52. Wu HT, Ou HY, Hung HC, Su YC, Lu FH, Wu JS, et al. A novel hepatokine, HFREP1, plays a crucial role in the development of insulin resistance and type 2 diabetes. Diabetologia. 2016;59:1732-42.

53. Calvaruso V. Hepassocin as a treatment for fulminant hepatic failure: will it translate from rats to human? Gut. 2010;59:709-10.

54. Demchev V, Malana G, Vangala D, Stoll J, Desai A, Kang HW, et al. Targeted deletion of fibrinogen like protein 1 reveals a novel role in energy substrate utilization. PLoS ONE. 2013;8:e58084.

55. Gao M, Yan H, Yin RH, Wang Q, Zhan YQ, Yu M, et al. Hepassocin is required for hepatic outgrowth during zebrafish hepatogenesis. Biochem Biophys Res Commun. 2015:463:466-71.

56. Wu HT, Chen SC, Fan KC, Kuo CH, Lin SY, Wang SH, et al. Targeting fibrinogen-like protein 1 is a novel therapeutic strategy to combat obesity. FASEB J. 2020;34:2958-67.

57. Watanabe T, Bertoletti A, Tanoto TA. PD-1/PD-L1 pathway and T-cell exhaustion in chronic hepatitis virus infection. J Viral Hepat. 2010;17:453-8.

58. Xia L, Liu Y, Wang Y. PD-1/PD-L1 blockade therapy in advanced nonsmall-cell lung cancer: current status and future directions. Oncologist. 2019:24:S31-41.

59. Sui H, Ma N, Wang Y, Li H, Liu X, Su Y, et al. Anti-PD-1/PD-L1 therapy for non-small-cell lung cancer: toward personalized medicine and combination strategies. J Immunol Res. 2018;2018:6984948.

60. Rizvi NA, Hellmann MD, Snyder A, Kvistborg P, Makarov V, Havel JJ, et al. Mutational landscape determines sensitivity to PD-1 blockade in nonsmall cell lung cancer. Science. 2015;348:124-8.

61. Qu J, Jiang M, Wang L, Zhao D, Qin K, Wang Y, et al. Mechanism and potential predictive biomarkers of immune checkpoint inhibitors in NSCLC. Biomed Pharmacother. 2020;127:109996.

62. Zhang X, Wang Y, Fan J, Chen W, Luan J, Mei X, et al. Blocking CD47 efficiently potentiated therapeutic effects of anti-angiogenic therapy in non-small cell lung cancer. J Immunother Cancer. 2019;7:346.

63. Allen E, Jabouille A, Rivera LB, Lodewijckx I, Missiaen R, Steri V, et al. Combined antiangiogenic and anti-PD-L1 therapy stimulates tumor immunity through HEV formation. Sci Transl Med. 2017;9.

64. Saarenheimo J, Eigeliene N, Andersen H, Tiirola M, Jekunen A. The value of liquid biopsies for guiding therapy decisions in non-small cell lung cancer. Front Oncol. 2019;9:129.

65. Kloten L, Krahn S. Circulating tumor cell PD-L1 expression as biomarker for therapeutic efficacy of immune checkpoint inhibition in NSCLC. Cells. 2019:8.

66. Chan KY, Lai PB, Squire JA, Beheshti B, Wong NL, Sy SM, et al. Positional expression profiling indicates candidate genes in deletion hotspots of hepatocellular carcinoma. Mod Pathol. 2006;19:1546-54.

67. Nayeb-Hashemi H, Desai A, Demchev V, Bronson RT, Hornick JL, Cohen $D E$, et al. Targeted disruption of fibrinogen like protein-1 accelerates hepatocellular carcinoma development. Biochem Biophys Res Commun. 2015;465:167-73.

68. Jung TW, Chung YH, Kim HC, Abd El-Aty AM, Jeong JH. Hyperlipidemiainduced hepassocin in the liver contributes to insulin resistance in skeletal muscle. Mol Cell Endocrinol. 2018;470:26-33.

69. Ou HY, Wu HT, Lin CH, Du YF, Hu CY, Hung HC, et al. The hepatic protection effects of hepassocin in hyperglycemic crisis. J Clin Endocrinol Metab. 2017;102:2407-15 
70. Liu Z, Ukomadu C. Fibrinogen-like protein 1, a hepatocyte derived protein is an acute phase reactant. Biochem Biophys Res Commun. 2008;365:729-34

71. Han NK, Jung MG, Jeong YJ, Son Y, Han SC, Park S, et al. Plasma fibrinogen-like 1 as a potential biomarker for radiation-induced liver injury. Cells. 2019;8.

72. Chen G, Feng Y, Sun Z, Gao Y, Wu C, Zhang H, et al. mRNA and IncRNA expression profiling of radiation-induced gastric injury reveals potential radiation-responsive transcription factors. Dose Response. 2019;17:1559325819886766

73. Jin H, Kang G-Y, Jeon S, Kim J-M, Park YN, Cho J, et al. Identification of molecular signatures involved in radiation-induced lung fibrosis. J Mol Med. 2018;97:37-47

74. Leu JI, Crissey MA, Leu JP, Ciliberto G, Taub R. Interleukin-6-induced STAT3 and AP-1 amplify hepatocyte nuclear factor 1-mediated transactivation of hepatic genes, an adaptive response to liver injury. Mol Cell Biol. 2001;21:414-24.

75. Batlle E, Massague J. Transforming growth factor-beta signaling in immunity and cancer. Immunity. 2019;50:924-40.

76. Murakami M, Kamimura D, Hirano T. Pleiotropy and specificity: insights from the interleukin 6 family of cytokines. Immunity. 2019;50:812-31.

77. Schmidt-Arras D, Rose-John S. IL-6 pathway in the liver: from physiopathology to therapy. J Hepatol. 2016;64:1403-15.

78. Yu HT, Yu M, Li CY, Zhan YQ, Xu WX, Li YH, et al. Specific expression and regulation of hepassocin in the liver and down-regulation of the correlation of HNF1alpha with decreased levels of hepassocin in human hepatocellular carcinoma. J Biol Chem. 2009:284:13335-47.

79. Zou S, Tong Q, Liu B, Huang W, Tian Y, Fu X. Targeting STAT3 in cancer immunotherapy. Mol Cancer. 2020;19:145.

80. Thilakasiri PS, Dmello RS, Nero TL, Parker MW, Ernst M, Chand AL. Repurposing of drugs as STAT3 inhibitors for cancer therapy. Semin Cancer Biol. 2021;68:31-46.

81. Furtek SL, Backos DS, Matheson CJ, Reigan P. Strategies and approaches of targeting STAT3 for cancer treatment. ACS Chem Biol. 2016;11:308-18.

82. Marzec M, Zhang Q, Goradia A, Raghunath PN, Liu X, Paessler M, et al. Oncogenic kinase NPM/ALK induces through STAT3 expression of immunosuppressive protein CD274 (PD-L1, B7-H1). Proc Natl Acad Sci U S A. 2008; 105:20852-7.

83. Wang J, Wei W, Tang Q, Lu L, Luo Z, Li W, et al. Oxysophocarpine suppresses hepatocellular carcinoma growth and sensitizes the therapeu tic blockade of anti-Lag-3 via reducing FGL1 expression. Cancer Med. 2020;9:7125-36

84. Liu S, Guo Y, Lu L, Lu J, Ke M, Xu T, et al. Fibrinogen-like protein 1 is a novel biomarker for predicting disease activity and prognosis of rheumatoid arthritis. Front Immunol. 2020;11:579228.

85. Han L, Ao X, Lin S, Guan S, Zheng L, Han X, et al. Quantitative comparative proteomics reveal biomarkers for dengue disease severity. Front Microbiol. 2019;10:2836

86. Dong Y, Simoes ML, Marois E, Dimopoulos G. CRISPR/Cas9-mediated gene knockout of Anopheles gambiae FREP1 suppresses malaria parasite infection. PLoS Pathog. 2018;14:e1006898.

87. Yu J, Li J, Shen J, Du F, Wu X, Li M, et al. The role of Fibrinogen-like proteins in cancer. Int J Biol Sci. 2021;17:1079-87.

88. Hanahan D, Weinberg RA. Hallmarks of cancer: the next generation. Cell. 2011;144:646-74

89. Su J, Morgani SM, David CJ, Wang Q, Er EE, Huang YH, et al. TGF-beta orchestrates fibrogenic and developmental EMTs via the RAS effector RREB1. Nature. 2020;577:566-71.

90. Xu J, Lamouille S, Derynck R. TGF-beta-induced epithelial to mesenchymal transition. Cell Res. 2009;19:156-72.

91. Li H, Batth IS, Qu X, Xu L, Song N, Wang R, et al. IGF-IR signaling in epithelial to mesenchymal transition and targeting IGF-IR therapy: overview and new insights. Mol Cancer. 2017;16:6.

92. Fazilaty H, Rago L, Kass Youssef K, Ocana OH, Garcia-Asencio F, Arcas A, et al. A gene regulatory network to control EMT programs in development and disease. Nat Commun. 2019;10:5115.

93. Bie F, Wang G, Qu X, Wang Y, Huang C, Wang Y, et al. Loss of FGL1 induces epithelialmesenchymal transition and angiogenesis in LKB1 mutant lung adenocarcinoma. Int J Oncol. 2019;55:697-707.
94. Zhang Y, Qiao HX, Zhou YT, Hong L, Chen JH. Fibrinogenlikeprotein 1 promotes the invasion and metastasis of gastric cancer and is associated with poor prognosis. Mol Med Rep. 2018;18:1465-72.

95. Onder TT, Gupta PB, Mani SA, Yang J, Lander ES, Weinberg RA. Loss of E-cadherin promotes metastasis via multiple downstream transcriptional pathways. Cancer Res. 2008;68:3645-54.

96. van Roy F, Berx G. The cell-cell adhesion molecule E-cadherin. Cell Mol Life Sci. 2008;65:3756-88.

97. Morrow CS, Porter TJ, Xu N, Arndt ZP, Ako-Asare K, Heo HJ, et al. Vimentin coordinates protein turnover at the aggresome during neural stem cell quiescence exit. Cell Stem Cell. 2020;26:558-68 e9.

98. Nakamura-Ishizu A, Suda T. Dynamic changes in the Niche with N-cadherin revisited: the HSC "Niche Herein." Cell Stem Cell. 2019;24:355-6.

99. Richardson AM, Havel LS, Koyen AE, Konen JM, Shupe J, Wiles WG, et al. Vimentin is required for lung adenocarcinoma metastasis via heterotypic tumor cell-cancer-associated fibroblast interactions during collective invasion. Clin Cancer Res. 2018;24:420-32.

100. Serres MP, Samwer M, Truong Quang BA, Lavoie G, Perera U, Gorlich D, et al. F-Actin interactome reveals vimentin as a key regulator of actin organization and cell mechanics in mitosis. Dev Cell. 2020:52:210-22.

101. Su Y, Li J, Shi C, Hruban RH, Radice GL. N-cadherin functions as a growth suppressor in a model of K-ras-induced PanIN. Oncogene. 2016;35:3335-41.

102. Lin X, Chai G, Wu Y, Li J, Chen F, Liu J, et al. RNA m(6)A methylation regulates the epithelial mesenchymal transition of cancer cells and translation of Snail. Nat Commun. 2019;10:2065.

103. Kim MS, Lee HS, Kim YJ, Lee DY, Kang SG, Jin W. MEST induces Twist1-mediated EMT through STAT3 activation in breast cancers. Cell Death Differ. 2019;26:2594-606.

104. Lin TC, Yang CH, Cheng LH, Chang WT, Lin YR, Cheng HC. Fibronectin in cancer: friend or foe. Cells. 2019;9.

105. Mohan A, Neequaye N, Malur A, Soliman E, McPeek M, Leffler N, et al. Matrix metalloproteinase-12 is required for granuloma progression. Front Immunol. 2020;11:553949.

106. Tsai HY, Fu SL, Tseng LM, Chiu JH, Lin CH. hnRNPK S379 phosphorylation participates in migration regulation of triple negative MDA-MB-231 cells. Sci Rep. 2019;9:7611.

107. Liu M, Yang J, Zhang Y, Zhou Z, Cui X, Zhang L, et al. ZIP4 promotes pancreatic cancer progression by repressing ZO-1 and claudin-1 through a ZEB1-dependent transcriptional mechanism. Clin Cancer Res. 2018;24:3186-96

108. Schwayer C, Shamipour S, Pranjic-Ferscha K, Schauer A, Balda M, Tada $M$, et al. Mechanosensation of tight junctions depends on ZO-1 phase separation and flow. Cell. 2019;179:937-52.

109. Lee SY, Jeong EK, Ju MK, Jeon HM, Kim MY, Kim CH, et al. Induction of metastasis, cancer stem cell phenotype, and oncogenic metabolism in cancer cells by ionizing radiation. Mol Cancer. 2017;16:10.

110. Du B, Shim JS. Targeting epithelial-mesenchymal transition (EMT) to overcome drug resistance in cancer. Molecules. 2016:21.

111. Lazarova D, Bordonaro M. ZEB1 mediates drug resistance and EMT in p300-deficient CRC. J Cancer. 2017:8:1453-9.

112. Wu X, Wu Q, Zhou X, Huang J. SphK1 functions downstream of IGF-1 to modulate IGF-1-induced EMT, migration and paclitaxel resistance of A549 cells: a preliminary in vitro study. J Cancer. 2019;10:4264-9.

113. Qi LN, Xiang BD, Wu FX, Ye JZ, Zhong JH, Wang YY, et al. Circulating tumor cells undergoing EMT provide a metric for diagnosis and prognosis of patients with hepatocellular carcinoma. Cancer Res. 2018;78:4731-44

114. Sun C, Gao W, Liu J, Cheng H, Hao J. FGL1 regulates acquired resistance to Gefitinib by inhibiting apoptosis in non-small cell lung cancer. Respir Res. 2020;21:210.

115. Chiu CF, Hsu MI, Yeh HY, Park JM, Shen YS, Tung TH, et al. Eicosapentaenoic acid inhibits KRAS mutant pancreatic cancer cell growth by suppressing hepassocin expression and STAT3 phosphorylation. Biomolecules. 2021;11.

116. Son Y, Shin NR, Kim SH, Park SC, Lee HJ. Fibrinogen-like protein 1 modulates sorafenib resistance in human hepatocellular carcinoma cells. Int J Mol Sci. 2021;22.

117. Villanueva A, Chiang DY, Newell P, Peix J, Thung S, Alsinet C, et al. Pivotal role of mTOR signaling in hepatocellular carcinoma. Gastroenterology. 2008:135:1972-83. 
118. Grabinski N, Ewald F, Hofmann BT, Staufer K, Schumacher U, Nashan $B$, et al. Combined targeting of AKT and mTOR synergistically inhibits proliferation of hepatocellular carcinoma cells. Mol Cancer. 2012;11:85.

119. de Streel G, Bertrand C, Chalon N, Lienart S, Bricard O, Lecomte S, et al. Selective inhibition of TGF-beta1 produced by GARP-expressing Tregs overcomes resistance to PD-1/PD-L1 blockade in cancer. Nat Commun. 2020;11:4545.

120. Barbi J, Pardoll D, Pan F. Treg functional stability and its responsiveness to the microenvironment. Immunol Rev. 2014:259:115-39.

121. Ohkura N, Hamaguchi M, Morikawa H, Sugimura K, Tanaka A, Ito Y, et al. T cell receptor stimulation-induced epigenetic changes and Foxp3 expression are independent and complementary events required for Treg cell development. Immunity. 2012;37:785-99.

122. Ohkura N, Sakaguchi S. Transcriptional and epigenetic basis of Treg cell development and function: its genetic anomalies or variations in autoimmune diseases. Cell Res. 2020;30:465-74.

123. Noman MZ, Desantis G, Janji B, Hasmim M, Karray S, Dessen $P$, et al. PD-L1 is a novel direct target of HIF-1alpha, and its blockade under hypoxia enhanced MDSC-mediated T cell activation. J Exp Med. 2014;211:781-90.

124. Alfaro C, Teijeira A, Onate C, Perez G, Sanmamed MF, Andueza MP, et al. Tumor-produced interleukin-8 attracts human myeloid-derived suppressor cells and elicits extrusion of neutrophil extracellular traps (NETs). Clin Cancer Res. 2016:22:3924-36.

125. Gabrilovich DI. Myeloid-derived suppressor cells. Cancer Immunol Res. 2017:5:3-8.

126. Lu X, Horner JW, Paul E, Shang X, Troncoso P, Deng P, et al. Effective combinatorial immunotherapy for castration-resistant prostate cancer. Nature. 2017:543:728-32.

127. Veglia F, Perego M, Gabrilovich D. Myeloid-derived suppressor cells coming of age. Nat Immunol. 2018;19:108-19.

128. Curiel TJ, Wei S, Dong H, Alvarez X, Cheng P, Mottram P, et al. Blockade of B7-H1 improves myeloid dendritic cell-mediated antitumor immunity. Nat Med. 2003;9:562-7.

129. Kim YJ, Won CH, Lee MW, Choi JH, Chang SE, Lee WJ. Correlation between tumor-associated macrophage and immune checkpoint molecule expression and its prognostic significance in cutaneous melanoma. J Clin Med. 2020;9.

130. Li X, Liu R, Su X, Pan Y, Han X, Shao C, et al. Harnessing tumor-associated macrophages as aids for cancer immunotherapy. Mol Cancer. 2019;18:177.

131. Singhal S, Stadanlick J, Annunziata MJ, Rao AS, Bhojnagarwala PS, O'Brien S, et al. Human tumor-associated monocytes/macrophages and their regulation of T cell responses in early-stage lung cancer. Sci Transl Med. 2019;11.

132. Hopkins RA, Connolly JE. The specialized roles of immature and mature dendritic cells in antigen cross-presentation. Immunol Res. 2012;53:91-107.

133. Yin W, Ouyang S, Li Y, Xiao B, Yang H. Immature dendritic cell-derived exosomes: a promise subcellular vaccine for autoimmunity. Inflammation. 2012;36:232-40.

134. Das M, Zhu C, Kuchroo VK. Tim-3 and its role in regulating anti-tumor immunity. Immunol Rev. 2017;276:97-111.

135. Ngiow SF, von Scheidt B, Akiba H, Yagita H, Teng MW, Smyth MJ. AntiTIM3 antibody promotes T cell IFN-gamma-mediated antitumor immunity and suppresses established tumors. Cancer Res. 2011;71:3540-51.

136. WolfY, Anderson AC, Kuchroo VK. TIM3 comes of age as an inhibitory receptor. Nat Rev Immunol. 2020;20:173-85.

137. Blake SJ, Dougall WC, Miles JJ, Teng MW, Smyth MJ. Molecular pathways: targeting CD96 and TIGIT for cancer immunotherapy. Clin Cancer Res. 2016;22:5183-8.

138. Chauvin JM, Zarour HM. TIGIT in cancer immunotherapy. J Immunother Cancer. 2020;8.

139. Nowak EC, Lines JL, Varn FS, Deng J, Sarde A, Mabaera R, et al. Immunoregulatory functions of VISTA. Immunol Rev. 2017;276:66-79.

140. Duraiswamy J, Freeman GJ, Coukos G. Therapeutic PD-1 pathway blockade augments with other modalities of immunotherapy T-cell function to prevent immune decline in ovarian cancer. Cancer Res. 2013;73:6900-12

141. Terawaki S, Chikuma S, Shibayama S, Hayashi T, Yoshida T, Okazaki T, et al. IFN-alpha directly promotes programmed cell death-1 transcription and limits the duration of T cell-mediated immunity. J Immunol. 2011;186:2772-9.

142. Wu C, Zhu Y, Jiang J, Zhao J, Zhang XG, Xu N. Immunohistochemical localization of programmed death-1 ligand-1 (PD-L1) in gastric carcinoma and its clinical significance. Acta Histochem. 2006;108:19-24.

143. Zerdes I, Matikas A, Bergh J, Rassidakis GZ, Foukakis T. Genetic, transcriptional and post-translational regulation of the programmed death protein ligand 1 in cancer: biology and clinical correlations. Oncogene. 2018;37:4639-61.

144. Zhang J, Dang F, Ren J, Wei W. Biochemical aspects of PD-L1 regulation in cancer immunotherapy. Trends Biochem Sci. 2018;43:1014-32.

145. Schalper KA, Carvajal-Hausdorf D, McLaughlin J, Altan M, Velcheti V, Gaule P, et al. Differential expression and significance of PD-L1, IDO-1, and B7-H4 in human lung cancer. Clin Cancer Res. 2017;23:370-8.

146. Woo SR, Turnis ME, Goldberg MV, Bankoti J, Selby M, Nirschl CJ, et al. Immune inhibitory molecules LAG-3 and PD-1 synergistically regulate T-cell function to promote tumoral immune escape. Cancer Res. 2012;72:917-27.

147. Huang CT, Workman CJ, Flies D, Pan X, Marson AL, Zhou G, et al. Role of LAG-3 in regulatory T cells. Immunity. 2004:21:503-13.

148. Workman CJ, Cauley LS, Kim IJ, Blackman MA, Woodland DL, Vignali DA. Lymphocyte activation gene-3 (CD223) regulates the size of the expanding $T$ cell population following antigen activation in vivo. J Immunol. 2004;172:5450-5.

149. Khan M, Arooj S, Wang H. NK cell-based immune checkpoint inhibition. Front Immunol. 2020;11:167.

150. Nagasaki J, Togashi Y, Sugawara T, Itami M, Yamauchi N, Yuda J, et al The critical role of CD4+ T cells in PD-1 blockade against MHC-IIexpressing tumors such as classic Hodgkin lymphoma. Blood Adv. 2020;4:4069-82.

151. Hemon P, Jean-Louis F, Ramgolam K, Brignone C, Viguier M, Bachelez $\mathrm{H}$, et al. MHC class II engagement by its ligand LAG-3 (CD223) contributes to melanoma resistance to apoptosis. J Immunol. 2011;186:5173-83.

152. Casati C, Camisaschi C, Novellino L, Mazzocchi A, Triebel F, Rivoltini L, et al. Human lymphocyte activation gene-3 molecules expressed by activated $\mathrm{T}$ cells deliver costimulation signal for dendritic cell activation. Immunol. 2008;180:3782-8.

153. Atkinson V, Khattak A, Haydon A, Eastgate M, Roy A, Prithviraj P, et al. Eftilagimod alpha, a soluble lymphocyte activation gene-3 (LAG-3) protein plus pembrolizumab in patients with metastatic melanoma. J Immunother Cancer. 2020;8.

154. He Y, Wang Y, Zhao S, Zhao C, Zhou C, Hirsch FR. sLAG-3 in non-smallcell lung cancer patients' serum. Onco Targets Ther. 2018;11:4781-4.

155. Lichtenegger FS, Rothe M, Schnorfeil FM, Deiser K, Krupka C, Augsberger $C$, et al. Targeting LAG-3 and PD-1 to enhance T cell activation by antigen-presenting cells. Front Immunol. 2018;9:385.

156. Niu B, Zhou F, Su Y, Wang L, Xu Y, Yi Z, et al. Different expression characteristics of LAG3 and PD-1 in sepsis and their synergistic effect on $T$ cell exhaustion: a new strategy for immune checkpoint blockade. Front Immunol. 2019;10:1888

157. Okazaki T, Okazaki IM, Wang J, Sugiura D, Nakaki F, Yoshida T, et al. PD-1 and LAG-3 inhibitory co-receptors act synergistically to prevent autoimmunity in mice. J Exp Med. 2011;208:395-407.

158. He Y, Yu H, Rozeboom L, Rivard CJ, Ellison K, Dziadziuszko R, et al. LAG-3 protein expression in non-small cell lung cancer and its relationship with PD-1/PD-L1 and tumor-infiltrating lymphocytes. J Thorac Oncol. 2017:12:814-23.

159. Rouhani SJ, Eccles JD, Riccardi P, Peske JD, Tewalt EF, Cohen JN, et al. Roles of lymphatic endothelial cells expressing peripheral tissue antigens in CD4 T-cell tolerance induction. Nat Commun. 2015;6:6771.

160. Zelba H, Bedke J, Hennenlotter J, Mostbock S, Zettl M, Zichner T, et al. PD-1 and LAG-3 dominate checkpoint receptor-mediated T-cell inhibition in renal cell carcinoma. Cancer Immunol Res. 2019;7:1891-9.

161. Sun L, Zhang L, Yu J, Zhou Y, Shi C, Wasan HS, et al. To be or not to be: whether anti-angiogenic agent combined with immune checkpoint inhibitoris necessary in the treatment of advanced or metastatic renal cell carcinoma. Med Oncol. 2020;37:15.

162. Wang Y, Dong T, Xuan Q, Zhao H, Qin L, Zhang Q. Lymphocyte-activation gene-3 expression and prognostic value in neoadjuvant-treated triple-negative breast cancer. J Breast Cancer. 2018;21:124-33. 
163. Du H, Yi Z, Wang L, Li Z, Niu B, Ren G. The co-expression characteristics of LAG3 and PD-1 on the T cells of patients with breast cancer reveal a new therapeutic strategy. Int Immunopharmacol. 2020;78:106113.

164. Grosso JF, Goldberg MV, Getnet D, Bruno TC, Yen HR, Pyle KJ, et al. Functionally distinct LAG-3 and PD-1 subsets on activated and chronically stimulated CD8 T cells. J Immunol. 2009;182:6659-69.

165. Guo M, Yuan F, Qi F, Sun J, Rao Q, Zhao Z, et al. Expression and clinical significance of LAG-3, FGL1, PD-L1 and CD8(+)T cells in hepatocellular carcinoma using multiplex quantitative analysis. J Transl Med. 2020;18:306.

166. Zhang L, Zhang X, Liu Y, Zhang T, Wang Z, Gu M, et al. PD-L1(+) aneuploid circulating tumor endothelial cells (CTECs) exhibit resistance to the checkpoint blockade immunotherapy in advanced NSCLC patients. Cancer Lett. 2020;469:355-66.

167. Sanmamed MF, Etxeberria I, Otano I, Melero I. Twists and turns to translating 4-1BB cancer immunotherapy. Sci Transl Med. 2019;11.

168. Wikenheiser DJ, Stumhofer JS. ICOS co-stimulation: friend or foe? Front Immunol. 2016:7:304

169. Xiao Z, Mayer AT, Nobashi TW, Gambhir SS. ICOS is an indicator of T-cell-mediated response to cancer immunotherapy. Cancer Res. 2020;80:3023-32.

170. Datar I, Sanmamed MF, Wang J, Henick BS, Choi J, Badri T, et al. Expression analysis and significance of PD-1, LAG-3, and TIM-3 in human non-small cell lung cancer using spatially resolved and multiparametric single-cell analysis. Clin Cancer Res. 2019;25:4663-73.

171. Kalbasi A, Ribas A. Tumour-intrinsic resistance to immune checkpoint blockade. Nat Rev Immunol. 2020;20:25-39.

172. Pitt JM, Vetizou M, Daillere R, Roberti MP, Yamazaki T, Routy B, et al. Resistance mechanisms to immune-checkpoint blockade in cancer: tumor-intrinsic and -extrinsic factors. Immunity. 2016;44:1255-69.

173. Zaretsky JM, Garcia-Diaz A, Shin DS, Escuin-Ordinas H, Hugo W, HuLieskovan S, et al. Mutations associated with acquired resistance to PD-1 blockade in melanoma. N Engl J Med. 2016;375:819-29.

174. Gao J, Shi LZ, Zhao H, Chen J, Xiong L, He Q, et al. Loss of IFN-gamma pathway genes in tumor cells as a mechanism of resistance to antiCTLA-4 therapy. Cell. 2016;167:397-404.

175. Rodig SJ, Gusenleitner D, Jackson DG, Gjini E, Giobbie-Hurder A, Jin C, et al. MHC proteins confer differential sensitivity to CTLA-4 and PD-1 blockade in untreated metastatic melanoma. Sci Transl Med. 2018;10.

176. McGranahan N, Rosenthal R, Hiley CT, Rowan AJ, Watkins TBK, Wilson GA, et al. Allele-specific HLA loss and immune escape in lung cancer evolution. Cell. 2017:171:1259-71 e11.

177. Andreae S, Buisson S, Triebel F. MHC class II signal transduction in human dendritic cells induced by a natural ligand, the LAG-3 protein (CD223). Blood. 2003;102:2130-7.

178. Liu C, Zheng S, Jin R, Wang X, Wang F, Zang R, et al. The superior efficacy of anti-PD-1/PD-L1 immunotherapy in KRAS-mutant non-small cell lung cancer that correlates with an inflammatory phenotype and increased immunogenicity. Cancer Lett. 2020;470:95-105.

179. Spranger S, Bao R, Gajewski TF. Melanoma-intrinsic beta-catenin signalling prevents anti-tumour immunity. Nature. 2015:523:231-5.

180. Grasso CS, Giannakis M, Wells DK, Hamada T, Mu XJ, Quist M, et al. Genetic mechanisms of immune evasion in colorectal cancer. Cancer Discov. 2018;8:730-49.

181. Holtzhausen A, Zhao F, Evans KS, Tsutsui M, Orabona C, Tyler DS, et al. Melanoma-derived Wnt5a promotes local dendritic-cell expression of IDO and immunotolerance: opportunities for pharmacologic enhancement of immunotherapy. Cancer Immunol Res. 2015;3:1082-95.

182. Zhao F, Xiao C, Evans KS, Theivanthiran T, DeVito N, Holtzhausen A, et al. Paracrine Wnt5a-beta-catenin signaling triggers a metabolic program that drives dendritic cell tolerization. Immunity. 2018;48:147-60 e7.
183. Joyce JA, Fearon DT. T cell exclusion, immune privilege, and the tumor microenvironment. Science. 2015;348:74-80.

184. Kim K, Skora AD, Li Z, Liu Q, Tam AJ, Blosser RL, et al. Eradication of metastatic mouse cancers resistant to immune checkpoint blockade by suppression of myeloid-derived cells. Proc Natl Acad Sci USA. 2014;111:11774-9.

185. Gong C, Yu X, Zhang W, Han L, Wang R, Wang Y, et al. Regulating the immunosuppressive tumor microenvironment to enhance breast cancer immunotherapy using pH-responsive hybrid membrane-coated nanoparticles. J Nanobiotechnology. 2021;19:58.

186. Martins F, Sofiya L, Sykiotis GP, Lamine F, Maillard M, Fraga M, et al. Adverse effects of immune-checkpoint inhibitors: epidemiology, management and surveillance. Nat Rev Clin Oncol. 2019;16:563-80.

187. Boutros C, Tarhini A, Routier E, Lambotte O, Ladurie FL, Carbonnel F, et al. Safety profiles of anti-CTLA-4 and anti-PD-1 antibodies alone and in combination. Nat Rev Clin Oncol. 2016:13:473-86.

188. Burova E, Hermann A, Dai J, Ullman E, Halasz G, Potocky T, et al. Preclinical development of the anti-LAG-3 antibody REGN3767: characterization and activity in combination with the anti-PD-1 antibody cemiplimab in human PD-1XLAG-3-Knockin mice. Mol Cancer Ther. 2019;18:2051-62

189. Lee JB, Ha SJ, Kim HR. Clinical insights into novel immune checkpoint inhibitors. Front Pharmacol. 2021;12:681320

190. Rossi G, Russo A, Tagliamento M, Tuzi A, Nigro O, Vallome G, et al. Precision medicine for NSCLC in the era of immunotherapy: new biomarkers to select the most suitable treatment or the most suitable patient. Cancers (Basel). 2020;12

191. Brody R, Zhang Y, Ballas M, Siddiqui MK, Gupta P, Barker C, et al. PD-L1 expression in advanced NSCLC: insights into risk stratification and treatment selection from a systematic literature review. Lung Cancer. 2017:112:200-15.

192. Ramjiawan RR, Griffioen AW, Duda DG. Anti-angiogenesis for cancer revisited: is there a role for combinations with immunotherapy? Angiogenesis. 2017;20:185-204

193. Tabchi S, Blais N. Antiangiogenesis for advanced non-small-cell lung cancer in the era of immunotherapy and personalized medicine. Front Oncol. 2017;7:52.

194. Jain RK. Antiangiogenesis strategies revisited: from starving tumors to alleviating hypoxia. Cancer Cell. 2014;26:605-22.

195. Larsen JE, Nathan V, Osborne JK, Farrow RK, Deb D, Sullivan JP, et al. ZEB1 drives epithelial-to-mesenchymal transition in lung cancer. J Clin Invest. 2016:126:3219-35.

196. Ebos JM, Lee CR, Cruz-Munoz W, Bjarnason GA, Christensen JG, Kerbel RS. Accelerated metastasis after short-term treatment with a potent inhibitor of tumor angiogenesis. Cancer Cell. 2009;15:232-9.

197. Manegold C, Dingemans AC, Gray JE, Nakagawa K, Nicolson M, Peters $S$, et al. The potential of combined immunotherapy and antiangiogenesis for the synergistic treatment of advanced NSCLC. J Thorac Oncol. 2017:12:194-207.

198. Rowshanravan B, Halliday N, Sansom DM. CTLA-4: a moving target in immunotherapy. Blood. 2018;131:58-67.

\section{Publisher's Note}

Springer Nature remains neutral with regard to jurisdictional claims in published maps and institutional affiliations. 